The results were summarized as followings.

(1) In the experimental hyperthyroidism by the thyradin injection, $\mathrm{QO}_{2}$ of erythrocyte is remarkably enhanced, but $\mathrm{QCo}_{2}$ does not show any variation.

(2) On the other hand, in the experimental hypothyroidism by bilateral thyroidectomy, the erythrocyte respiration decreases after long times. (about thirty days).

(3) By the injection of cortisone acetate, $\mathrm{QO}_{2}$ does not show any variation distinctly, but $\mathrm{QCo}_{2}$ and RQ are suppressed.

(4) By the injection of desoxycorticosterone acetate, the erythrocyte respiration is remarkably suppressed.

(5) By the bilateral adrenalectomy, the erythrocyte respiration decreases remarkably.

(6) When a small quantity of testosterone propionate was injected on the male rabbits, the erythrocyte respiration is enhanced, but on the female this tendency is not distinct.

(7) By the extirpation of the testicles, the erythrocyte respiration decreases after long time. (about fifty days).

(8) When a small quantity of estradiol benzoate was injected, the erythrocyte respiration is suppressed. Especially, this tendency is remarkable on the males.

(9) By the extirpation of the ovaries, the erythrocyte respiration was not influenced after long time. (about fifty days).

(10) From the overmentioned results, I can presume that the erythrocyte respiration was influenced by rndocrine functions excepting the effects of the blood regeneration showed by the variations of reticu'ocyte count.

\title{
Measurement of Serum Ins alin Activity and the Investigation about the Nature of Diabetes Mellitus
}

\author{
By
}

\section{Kentaro OKUMURA}

1st Department of Medicine, Kyoto Pref. Univ. of Med. (Director: Associate Prof. H. Yoshida, M.D.)

1) The author investigated about the measurement of serum insulin activity, on the basis of Gemmill's observation, that the isolated rat diaphgram uptakes glucose in the glucose containing solution and the glucose uptake is increased by the addition of insulin to the solution.

2) Wistar strain rats were bred about for 7 days with solid food (Oriental Co. made) under the condition of temperature $22 \pm 5^{\circ} \mathrm{C}$, and were abstained from the food for 15 hours before experiment.

3) These rats were sacrificed by decapitation, and the diaphragms were immediately removed, each of them were dissected in 4 pieces. So-called "quartardiaphragm technique of pooled method" was used for this investigation.

4) Phosphate buffer solution containing $200 \mathrm{mg} / \mathrm{dl}$. sugar was used for medium. For the incubator, the author used the manometer flask of Warburg's apparatus. The flask contains one-fourth of diaphragm, medium and $95 \sim 100 \% \mathrm{O}_{2}$, incubated for 75 minutes at $38^{\circ} \mathrm{C}, 90$ rounds shaking per minute. 
5) Glucose uptake of diaphgram per 1 gram (dry weight) in the medium before and after incubation, the mean values of four quartardiaphgrams from four rats were used. This value means basal uptake.

The difference between glucose uptake in the medium containing test solution and basal uptake means extraglucose uptake. When used insulin solution of known concentration to medium, this difference called as "insulin effect".

6) It became clear from the experiment, that the relation between insulin effect ( $Y$ ) and insulin concentration $(\mathrm{X})$ could be expressed by means of next equation.

$$
\log \mathrm{Y}=3 / 10 \log \mathrm{X}+\log 40
$$

7) Insulin value (insulin activity in sera) in normal subjects and diabetic patients, resulted as follows.

$$
\begin{array}{ll}
\text { normal subjects } & 0.339 \pm 0.08 \mathrm{mu} / \mathrm{ml} . \\
\text { diabetic patients } & 0.125 \pm 0.115 \mathrm{mu} / \mathrm{ml} . \\
\text { normal rabbits } & 0.355 \pm 0.125 \mathrm{mu} / \mathrm{ml} . \\
\text { alloxan diabetic rabbits } & 0.00 \sim 0.082 \mathrm{mu} / \mathrm{ml} . \\
\text { normal dogs } & 0.158 \pm 0.032 \mathrm{mu} / \mathrm{ml} . \\
\text { pancreatectomized dogs } & 0.00 \sim<0.01 \mathrm{mu} / \mathrm{ml} .
\end{array}
$$

these values were the averages of $5-10$ cases.

8) The remainings of injected insulin in blood of diabetic patients retarded than those by normal bodies, and moreover, these insulin in blood still retained its activity. Same results were obtained from the experimental diabetic animals.

9) Glucose uptake and insulin effect of the diaphragm from alloxanized rat deareased than those of controls.

10) From the result described in 7), 8), and 9) the author proved that insulin in blood decreased on diabetic patients, and diabetes mellitus is not caused by decreasing of activated insulin, but rather by decreasing of insulin utilizing ability.

11) Glucagon decreases glucose uptake and insulin activity in peripheral tissues, and so it acts as insulin inhibitor. 


\title{
横隔膜法に依る血中 Insulin 測定と糖尿病の 本態に関する検討
}

\author{
京都府立医科大学第一内科教室（指導 吉田秀雄助教授）
}

奥 村 賢 太 郎

（本論文の要旨は昭和 34 年 4 月第 32 回日本内分泌学会に於て発表した。亦昭和 34 年 6 月第 2 回日本糖尿病学 会に於ける，吉田助教授の宿題シンポジウム「インシュリンの測定法と代謝」の一部をなすものである)

目次

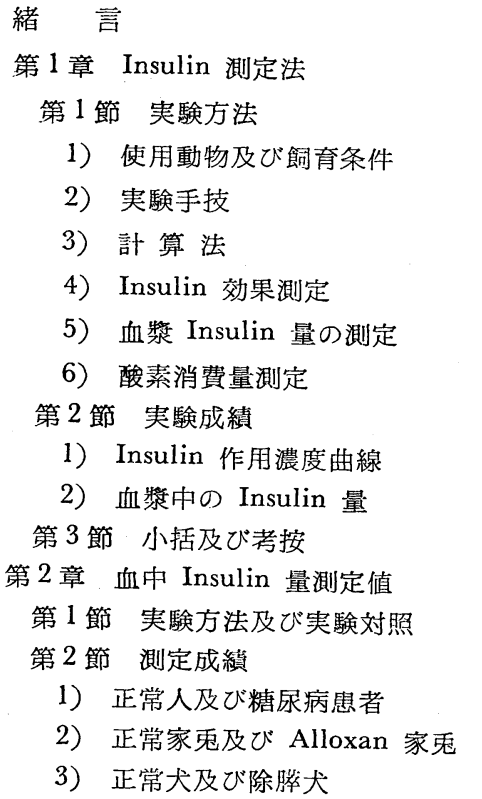

緒言

1 章 Insulin 测定法

1）使用動物及び飼育条件

2）実験手技

3) 計 算 法

Insulin 効果測定

量の測定

6) 酸素消費量測定

1） Insulin 作用濃度曲線

2）血漿中の Insulin 量

第 3 節 小括及び考按

2 章，血中 Insulin 量測定值

第 1 節 実験方法及び実験対照

第 2 節 測定成結

2）正常家鬼及び Alloxan 家鬼

3)正常犬及び除粨犬
第 3 節 小括及び考按

第 3 章 Insulin 負荷時化於ける血中 Insulin 量の変動

第 1 節 実験方法及び実験対照

第 2 節，実験成績

1）正常人と糖尿病患者

2) 正常家躳と Alloxan 家乘

3）正常犬と除猝犬

第 3 節 小括及び考按

第4 章 Insulin 作用機序に対する 2.3 の 検討

第 1 節 Alloxan ラット横隔膜の Insulin effect

第 2 節 Insulin effect に及ぼす Glucag on の影響

第 3 節 小括及び考按

結語

参考文献

\section{緒}

言

Insulin は最近 Sanger ${ }^{1}$ 亿依り，その構造式が決定されたとは云え，未だ之を物理化学的に定量する事は 不可能な状態にある．血中の Insulin 量を適確に測定し得るならば，Insulin の分泌，代謝，作用機序を明 らかにする事が出来るのみならず，糖尿病の原因探究に，病型分類に，治療に，臨床分野への応用価值は真 に大きなあのがある. 最近10数年の間 Insulin 測定に関する研究が重ねられ, 現在血中 Insulin は in vitro と in vitro の 2 つの方法に依り行われている. Insulin は蛋白ホルモンであるので両方法とあ, Insulinの 特異作用を利用した生物学的測定法である事は勿論である。

in vitro の方法は剔出せられたラット横隔膜が一定の Medium より葡萄糖を uptake する速度を Insulin が促進する事に着目した方法である。

即ち, Gemmill 2)3) がラットの剔出横隔膜の葡萄糖摄取能は, Medium 中に Insulin を添加する事に依り 促進されると云う事実を発見して以来，乙の現象を利用して血中 Insulin 量を湘定しようとする試は多く 
の学者に依つて報告されている. Stadie 及び Zapp ${ }^{4}$ ，Krahl 及び Park ${ }^{5}$ ，Permutter ${ }^{6}$ 等は Medium 中に存在 する Insulin 量とラット横隔膜の Glucose uptake 促進効果との間には, 一定関係が成立し, Insulin 量を

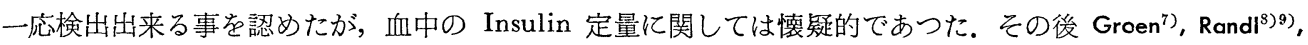

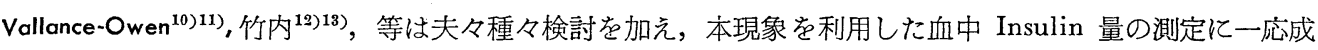
功した. 併し血中 Insulin の定量に成功した諸家の間にも，その最低検出濃度，精密度，測定した血中 Insulin 濃度などに関しては，相当な差違が認められる。乙の原因は Willebrands et $\mathrm{al}^{14)}$ は今日尚不明であ るとしているが，竹内 ${ }^{15)}$ は測定に必要な基礎条件が充分確立されていないてとに最大の原因がある事を指摘 し，乙の方法が厳密に規定された諸条件に従つて行われるならば，在来の諸方法に比較して優るとも劣らな い優秀な方法であると云つている．著者は Gemmill ${ }^{23)}$ ，竹内 ${ }^{15}$ )等のラット横隔膜法に準じて血中の Insulin 量を測定する事に成功した。

又糖尿病の核心をなす高血糖惹起原因は, Insulin の相対的欠点 ${ }^{16)}$ 亿依る代謝調節障碍 ${ }^{17)}$ と考えられてい るが，之は Insulin の分泌が障碍せられるのか，抗 Insulin ホルモンによるのか，或はインシュリナーゼ 等に依り Insulin が分解せられる為加等種々論議せられて来た。一方糖尿病患者の中には Insulin の大量 投与に対しても，比較的效果の少ない Insulin 耐性を現わす患者が存在する。我々は糖㽷病患者の体内に 於て Insulin は存在するが，何等かの処理を受けて活動し得なくなつたものか，或はInsulin が本当に少 ないのかさえ確実に云い得ない状態にあつた，本研究に於ては，Insulin の測定成功に次いで，ての点を究 明する為正常体と糖尿病体の血中 Insulin 量を測定比較検討し，更には生体内に投与せられた Insulin 活性 の変化を観察し，糖尿病の原因解明に重大なる鍵を握る Insulin の代謝 及び作用機序に若干の考察を加え t.

\section{第一章 Insulin 測 定 法}

\section{第 1 節 実 験 方 法}

\section{1）使用動物及び飼育条件}

$22 \pm 5^{\circ} \mathrm{C} の$ 温度下に於て Oriental 固型飼料を以て，1 週間飼育せる体重 $120 \mathrm{~g}$ 前後の Wister 系の Rat を使用した，動物の発育度に関しては，Willebrands et $\mathrm{al}^{18}$ は幼若白鼠横隔膜が糖利用に最も Sensitivityが 良いと云つているので著者も之に準じた.

\section{2) 実験手技}

横隔膜使用実験方法は Gemmill'3) の変法に從い個体差を尠くする為，Pooled method の Quartardiaphragm technique を採用した. 上記の Rat を15時間絶食後，断頭屠殺し，速かに横隔膜を剔出する，その 後直ちに $5^{\circ} \mathrm{C}$ 以下に冷却せる Phosphate buffer $(\mathrm{pH} 7.4)$ に浸す. Phosphate buffer は $0.9 \% \mathrm{NaCl} 80$ 容 に $0.1 \mathrm{~mol} \mathrm{~K} \mathrm{~K}_{2} \mathrm{HPO}_{4}$ 20容を混合し， $\mathrm{HCl}$ を小量加えて $\mathrm{pH} 7.4$ になる様調製したものである. 剔出 した横隔膜は液中に於て周囲の結合組織をピンセットで取り除いた後，Phosphate buffer で充分湿めらせ た濾紙上に伸展し，鈜で手早く濾紙と共に背側の三角部を切除し，又周辺のギザギザになつた部分を滑らか に切り整える．左右前後略々等重量なる様 4 分し，序め $0.2 \%$ の葡萄糖を含むPhosphate buffer 2cc を Incubation medium として用意した Flask 内に1個ずつ入れるのであるが，その前に別の容器に用意した 同液に一応浸し，良く水分を除いてから移し入れる. Rat 4 匹を以て 1 組となし，第 1 図に示す如く 4 分法 となし，各 Flask に夫々異つた横隔膜片を入れ，4 個を 1 組として，出来る限り個体差及び部分差を無く する様にした，横隔膜片を移し入れた後，各 Flask を軽く振盪混和して $0.1 \mathrm{cc}$ を取り，糖濃度測定に供す る.

次い Manometer につなぎ酸素を充媜する. 以上横隔膜剔出後, Incubation する迄の時間は約60分と した. 12個の Flask を Warburg 検圧装置 ${ }^{19}$ 亿連結し， $38^{\circ} \mathrm{C}$ 毎分90回転で75分（溶器内液か洹温槽と等温 になる迄の15分と酸素消費測定の60分の和）Incubation した．充媜ガスには95〜 $100 \% の O_{2}$ を使用した．尚 
Fig. 1 Quartardiaphragm technique
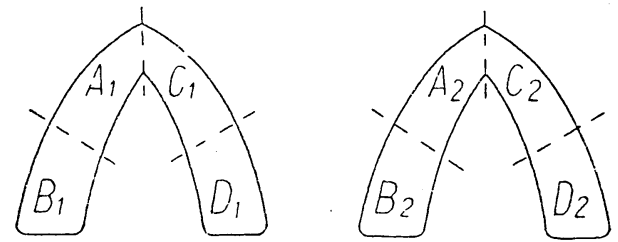

First group

Second group

Third group
1

$\mathrm{A}_{1}$

5

$\mathrm{B}_{1}$

9

$\mathrm{C}_{1}$
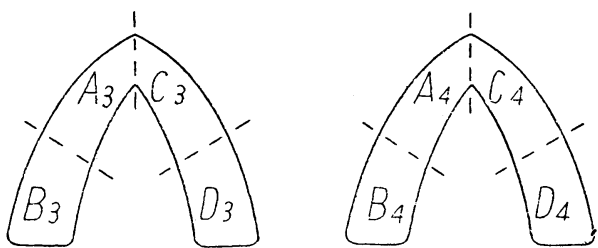

$4 \leftarrow$ Flask Number

$\mathrm{D}_{4}$

8

$\mathrm{A}_{4}$

12

$\mathrm{B}_{4}$

副室には $10 \% \mathrm{KOH} 0.2 \mathrm{cc}$ を入れ，併せて酸素消費量屯測定した. Incubation 前後の Medium 中の糖濃 度を Hagedorn-Jensen 氏法に依り测定し，Medium 中の横隔膜片は $90^{\circ} \mathrm{C}$ て 24 時間乾燥後重量測定を行 つた.

\section{3）計 算 法}

横隔膜の葡萄糖掑取量は Incubation medium 中の糖濃度の減少及び棤榢膜の乾燥重量より，次式を以て 算出し，各組 4 個の計算值を平均した做を以てそれとした。

Glucose uptake $=\frac{\text { Incubation 前の糖漂度-Incubation 後の糖濃度 }(\mathrm{mg} / \mathrm{dl})}{\text { 乾 燥 重 舅 }(\mathrm{mg})} \times 20$

\section{上式は}

横㢳膜雷量を Wmg とすると，

Incubation 前の糖濃度 : $\mathrm{amg} / \mathrm{dl}$

Incubation 後の糖䢅度 : bmg/dl

Medium は $2.0 \mathrm{cc}$

$$
\begin{aligned}
& \frac{\mathrm{a} \times 2}{100} \mathrm{mg} \cdots \cdots \cdots \cdot \cdots \cdot \mathrm{cc} \text { 中の糖量（前） } \\
& \frac{\mathrm{b} \times 2}{100} \mathrm{mg} \cdots \cdots \cdots \cdots \cdot 2 \mathrm{cc} \text { 中の糖量（後） } \\
& \therefore\left(\frac{2 \mathrm{a}}{100}-\frac{2 \mathrm{~b}}{100}\right) \mathrm{mg} \text { …... Incubation 後に } 2 \mathrm{cc} \text { 中の減少した糖舅 } \\
& \therefore \text { 乾燥重量 } 1 \mathrm{mg} \text { の糖湶取量は } \\
& \frac{2(a-b)}{100} \div W=\frac{2(a-b)}{100 W} \\
& \therefore 1 \mathrm{~g} \text { では } \frac{2(\mathrm{a}-\mathrm{b})}{100 \mathrm{~W}} \times 1000=\frac{\mathrm{a}-\mathrm{b}}{\mathrm{W}} \times 20
\end{aligned}
$$

Incubation medium に葡萄糖加 Phosphate buffer の子を使用した場合の糖提取量をその横隔膜の Basal uptake とした. 3 組の Manometer flask の中第 1 組には $200 \mathrm{mg} / \mathrm{dl}$ Sugar-Phosphate buffer のみ, 他に は被験液を夫々添扸し埸合，後者の Glucose uptake より Basal uptake を差引いた值を以て，被験液に よる Extraglucose ( (uptake) 殊にその被験液に Insulin 溶液を使用した場合には, Insulin effect とした。

\section{4) Insulin 効果測定}

前述の 3 組の Flask に Medium 1.6cc を入れ結晶 Insulin を $0.2 \%$ 葡萄糖含有の Phosphate buffer に て稀橎し，0.5cc 中に 2000mu. 200mu. 20mu. 2.0mu. 0.2mu. 0.02mu. 含有液を作り，之を加えて $2.1 \mathrm{cc}$ 
となし，その中 $0.1 \mathrm{cc}$ は Incubation 前の糖濃度測定に供し， medium lcc 中に Insulin 含有量が夫々 $1000 \mathrm{mu} .100 \mathrm{mu} .10 \mathrm{mu} .1 \mathrm{mu} .0 .1 \mathrm{mu}$. 0.01mu. となる如くした. 夫々の濃度に於ける Glucose uptake よ り Basal uptake を差引いたものを各濃度に於ける Insulin effect として作用濃度曲線を画いた，尚 Insulin は結晶 Novo Regular Insulin (1mg 23 unit) のみを使用した.

5）血漿 Insulin 量の測定

採血した静脈血に極く少量の弗化ソーダを加え，嬯心血漿を分離し，予めその一部を以て糖濃度を測定し ておき, 次で Flask 中に 1.6cc の Medium に 0.5cc の血獎を加え, 糖濃度が 0.2\%になる様 Phosphate buffer に溶解する葡萄糖の量を調節し，かくして得た $0.2 \%$ の葡萄糖濃度を有する混合液 4 倍稀釈血等 を Medium として，他の組の Flask に入れて Incubation を行い，第1組の Basal uptake を差引いた 量を被験稀粎血漿に依る Extraglucose uptake (

この Suptake に匹敵する Insulin 量を Insulin 作用濃度標準直線より求め，4 倍したものを血漿 $1 \mathrm{cc}$ 中 の Insulin 量とした.

\section{6) 酸素消費量測定}

横隔膜の $\mathrm{QO}_{2}$ 測定には Warburg 直接法 ${ }^{19}$ に依り $38^{\circ} \mathrm{C}$ 恒温槽中にて Incubation を行い, Flask 中の 内圧が外気圧と平衡に達した後 (15分後) 活栓を閉じ，60 分後の横隔膜の消費せる酸素量 $(\mathrm{H})$ を Manometer の分圧差に依り测定し次式より計算した。

$$
\mathrm{QO}_{2}=\frac{\mathrm{H} \cdot \mathrm{KO}_{2}}{\mathrm{Wt}}
$$

\section{$\mathrm{H}$ : Manometer の分圧差}

$\mathrm{KO}_{2}$ : 酸素に関する签器恒数

$\mathrm{W}:$ 横隔膜の乾燥重量

$\mathrm{t}$ : 測定時間 (1 時間)

Table 1 Promotion of Glucose uptake by Insulin

\begin{tabular}{|c|c|c|c|c|c|c|c|c|}
\hline Medium & $\begin{array}{c}\text { Flask } \\
\text { Number }\end{array}$ & $\begin{array}{l}\text { Number of } \\
\text { Quartar- } \\
\text { Diaphagm } \\
\text { alone }\end{array}$ & \begin{tabular}{|} 
glucose conc. \\
before Incu- \\
bation \\
$(\mathrm{mg} / \mathrm{dl})$
\end{tabular} & $\begin{array}{l}\text { glucose conc. } \\
\text { after Incub- } \\
\text { ation } \\
\quad(\mathrm{mg} / \mathrm{dl})\end{array}$ & $\begin{array}{c}\text { glucose } \\
\text { uptake } \\
(\mathrm{mg} / \mathrm{dl})\end{array}$ & $\begin{array}{l}\text { dry weight } \\
\text { of Diaphr- } \\
\text { agm } \\
(\mathrm{mg})\end{array}$ & $\mathrm{QO}_{2}$ & $\begin{array}{l}\text { glucose uptake } \\
\text { /lgrdry weight } \\
\text { diaphr. } \\
\text { (mg/dl/gr) }\end{array}$ \\
\hline \multirow{5}{*}{ 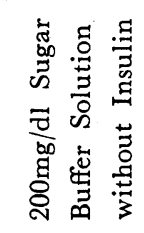 } & 1 & $A_{1}$ & 205 & 190 & 15 & 13.25 & 6.34 & 22.64 \\
\hline & 2 & $\mathrm{~B}_{2}$ & 205 & 193 & 12 & 12.16 & 6.21 & 19.74 \\
\hline & 3 & $\mathrm{C}_{3}$ & 205 & 195 & 10 & 8.75 & 6.03 & 22.86 \\
\hline & 4 & $\mathrm{D}_{4}$ & 203 & 192 & 11 & 11.03 & 6.31 & 19.94 \\
\hline & \multicolumn{4}{|c|}{ Average } & \multicolumn{2}{|c|}{ (Basal uptake) } & 6.22 & 21.29 \\
\hline \multirow{5}{*}{ 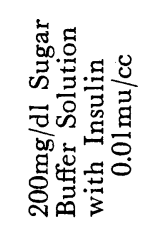 } & 5 & $\mathrm{~A}_{4}$ & 210 & 195 & 15 & 12.38 & 6.41 & 24.22 \\
\hline & 6 & $B_{1}$ & 204 & 191 & 13 & 11.56 & 7.02 & 22.49 \\
\hline & 7 & $\mathrm{C}_{2}$ & 208 & 192 & 16 & 13.01 & 6.86 & 24.57 \\
\hline & 8 & $\mathrm{D}_{3}$ & 209 & 197 & 12 & 11.50 & 6.84 & 20.86 \\
\hline & \multicolumn{6}{|c|}{ Average } & 6.78 & 23.03 \\
\hline \multirow{5}{*}{ 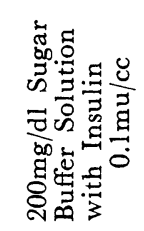 } & 9 & $\mathrm{~A}_{3}$ & $20 \widehat{~}$ & 191 & 15 & 11.67 & 7.01 & 25.71 \\
\hline & 10 & $\mathrm{~B}_{4}$ & 208 & 196 & 12 & 11.25 & 6.36 & 21.32 \\
\hline & 11 & $\mathrm{C}_{1}$ & 209 & 196 & 13 & 10.37 & 8.01 & 25.07 \\
\hline & 12 & $\mathrm{D}_{2}$ & 205 & 191 & 14 & 11.01 & 7.01 & 25.42 \\
\hline & \multicolumn{6}{|c|}{ Average } & 7.097 & 24.38 \\
\hline
\end{tabular}




\section{第 2 節 実験成績}

\section{1) Insulin 作用濃度曲線}

Medinm 中の Insulin 濃度を種々変化せしめ，その際の Glucose uptake を第 1 表の如く現わした。 即 ち各 Rat 横隔膜の 4 分片を前述の如く組合せて，個体差，部分差を尠くし，各組 4 個の平均值を以てその Medium に於ける Glucose uptake とした. 第 1 表より Basal uptake は $21.29 \mathrm{mg} / \mathrm{dl} / \mathrm{g}, 1 \mathrm{cc}$ 中 $0.01 \mathrm{mu}$ の Insulin を含有せる場合は $23.03 \mathrm{mg} / \mathrm{dl} / \mathrm{g}, 1 \mathrm{cc}$ 中 $0.1 \mathrm{mu}$ の場合は $24.38 \mathrm{mg} / \mathrm{dl} / \mathrm{g}$ と増大し, $0.01 \mathrm{mu}$ /cc 濃度に於ける Juptakeは $1.74 \mathrm{mg} / \mathrm{dl} / \mathrm{g}, 0.1 \mathrm{mu} / \mathrm{cc}$ 濃度に於ける Juptake は $3.09 \mathrm{mg} / \mathrm{dl} / \mathrm{g}$ とな る。その場合に於ける $\mathrm{QO}_{2}$ は夫々 6.22, 6.78, 7.097 である。各濃度に於ける Juptake は第 2 表 (A)

Fig. 2(A) The effect of increasing concentrations of Insulin upon the glucose utilization of the isolated rat diaphragm expressed as a logdose of Insluin response curve.

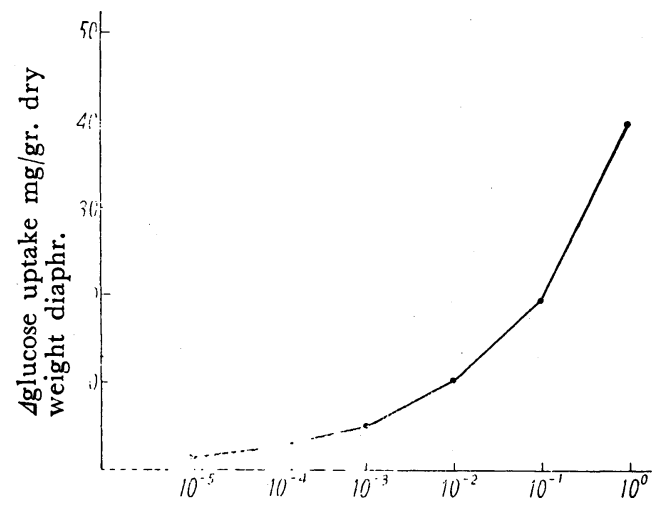

Fig. 2(B) Standard regression line

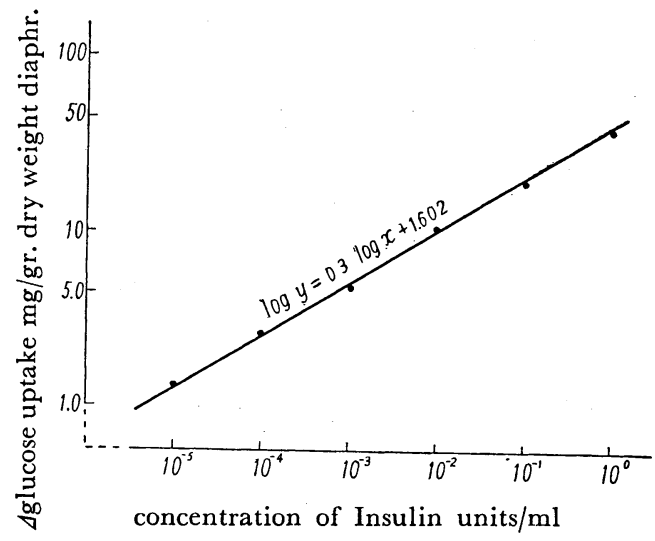

concentration of Insulin units/ml

の如くである. 各成績の平均値は $0.01 \mathrm{mu} / \mathrm{cc}$ で $1.37 \mathrm{mg} / \mathrm{dl} / \mathrm{g}, 0.1 \mathrm{mu} / \mathrm{cc}$ で $2.66 \mathrm{mg} / \mathrm{dl} / \mathrm{g}, 1.0 \mathrm{mu} / \mathrm{cc}$ で $4.74 \mathrm{mg} / \mathrm{dl} / \mathrm{g}, 10 \mathrm{mu} / \mathrm{cc}$ で $10.44 \mathrm{mg} / \mathrm{dl} / \mathrm{g}, 100 \mathrm{mu} / \mathrm{cc}$, で $19.66 \mathrm{mg} / \mathrm{dl} / \mathrm{g}, 1000 \mathrm{mu} / \mathrm{cc}$ で $39.91 \mathrm{mg} /$ $\mathrm{dl} / \mathrm{g}$ であり, $\mathrm{QO}_{2}$ は Insulin を Medium に加えない場合は第 2 表 Bの如く，6.30 各濃度の Insulin が 添加された場合は夫々 $6.32,6.21,6.39,6.36,6.38,6.39$ で有意の差を認めない. 夫々の標準偏差は 0.53 , $0.47,0.50,0.39,0.55,0.54,0.60$ である。乙の成績より Insulin effect は Insulin の対数濃度に刘し て第 2 図(A)の如く拋物線状となる。従来橫隔膜法に於ては Insulin 濃度 $0.01 \mathrm{mu} よ り 10 \mathrm{mu}$ の範囲に

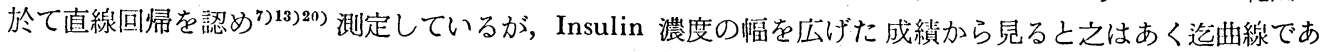

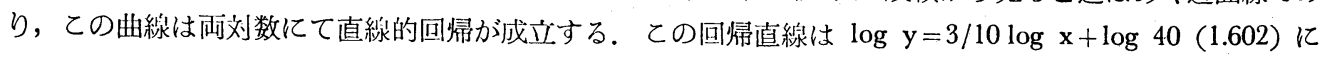

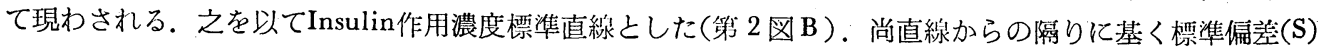
は 0.7081 である.

\section{2）血漿中の Insulin}

此処に於ては血漿中の Insulin 活性（以下之を Insulin 量とする）測定の一奉験成績を示した. （第 2 章以下の実験成績は, 第 3 表の如くして求めた成績のみを挙げた）即ち Basal uptake は $21.82 \mathrm{mg} / \mathrm{dl} / \mathrm{g}$, 被験血漿加 Medium に於ける Glucose uptake は第 1 例に於て $24.50 \mathrm{mg} / \mathrm{dl} / \mathrm{g}$ ，第 2 例に於ては 25.16 $\mathrm{mg} / \mathrm{dl} / \mathrm{g}$ となり夫々の Auptake は 2.68，3.34，であり，標準直線より，夫々 $0.12 ， 0.26$ を得る. 之に 稀釈倍数の 4 を乗じて，血漿 $1 \mathrm{cc}$ 中の Insulin 量は $0.48 \mathrm{mu} / \mathrm{cc}, 1.04 \mathrm{mu} / \mathrm{cc}$ を得る. 尚血漿を加えた場 
Table 2 (A) $\Delta$ uptake of rat diaphragm im $200 \mathrm{mg} / \mathrm{dl}$ sugar-phosphate buffer solution with variety concentration of insulin by quartardiaphragm technique.

(Basal uptake : $20.85 \mathrm{mg} / \mathrm{dl} / \mathrm{gr}$. dry weight)

\begin{tabular}{l|r|r|r|r|r|r}
\hline $\begin{array}{l}\text { conc. of added } \\
\text { Insulin u/cc }\end{array}$ & $10^{-5}$ & $10^{-4}$ & $10^{-3}$ & $10^{-2}$ & $10^{-1}$ & $10^{\circ}$ \\
\hline & 1.45 & 2.90 & 5.62 & 10.84 & 19.61 & 41.08 \\
& 1.52 & 3.41 & 4.68 & 10.80 & 18.93 & 39.86 \\
& 0.77 & 2.46 & 4.65 & 9.36 & 20.38 & 40.35 \\
& 1.32 & 2.26 & 5.08 & 9.60 & 21.21 & 38.95 \\
& 0.60 & 2.67 & 4.82 & 11.13 & 19.69 & 39.27 \\
& 1.23 & 3.47 & 4.79 & 10.21 & 21.13 & 40.80 \\
& 2.09 & 2.76 & 3.99 & 11.36 & 19.70 & 40.87 \\
& 1.20 & 2.30 & 4.50 & 9.93 & 21.50 & 40.76 \\
& 1.65 & 3.05 & 4.80 & 9.27 & 20.15 & 38.35 \\
& 1.97 & 2.86 & 4.83 & 10.16 & 19.55 & 38.57 \\
& & 2.68 & 4.88 & 9.13 & 20.17 & 41.23 \\
& & 2.84 & 5.67 & 9.58 & 19.36 & 40.59 \\
& & 1.87 & 5.15 & 11.16 & 20.34 & 39.20 \\
& & 2.33 & 5.77 & & & 39.89 \\
& & 2.79 & & & & \\
\hline \multirow{4}{*}{ Average } & 1.37 & 2.66 & 4.74 & 10.44 & 19.66 & 39.91 \\
\hline
\end{tabular}

合の $\mathrm{QO}_{2}$ は 8.45，8.41 と増加を見た。 之は第 2 章以下の成績には挙げないが血漿を加えた場合の $\mathrm{QO}_{2}$ は加えない場合の $\mathrm{QO}_{2}$ に比べて平均 $23.78 \%$ の増加を見た。

\section{第3節 小括及ひ考按}

Insulin の定量にあたつては，厳密に規定された測定条件を忠実に履行せねばなら好，以下著者が Insulin 量の測定にあたり用いた方法に文献的考察を加味して述べる.

横隔膜法は生物学的作用に依るむのであるから，使用ラットの条件に依つても甚だしい卦違がある，著者 は体重 $120 \mathrm{~g}$ 前後の Wister 系ラットを使用したが，交献的には Wistar 系 (Randle) ${ }^{8)}$, Hishaw 系 (Stadie et al) $)^{4}$, Sprague-Dawlley系 (Hansen et al) ${ }^{21)}$, Anheuser-Busch 系 (Krahl et al) ${ }^{22)}$ 等がある. Krahl and Cori ${ }^{22)}$ は Anheuser-Busch 系之 Sprague-Dawley 系との横隔膜の Insulin effect には殆んど差違はないと 云つている．著者はWister 系以外は使用していないが之で充分と思われる．次に雌雄の别については考虑 する事なく使用したが，倠は雄に比して栽萄糖利用能が低い (Devel and Davis) ${ }^{23)}$ と云うあの，或は Glucose oxydation の能率加ら, 組織内に掑取された葡萄糖が糖原に合成される場合と Glycolysis を受けて Pyruvate になる経過とを考えると，雌では前者は雄より盛んであり，雄は後者の割合が多い（Kerly and Ottaway $)^{24)}$ と云うもの等があるが，竹内等 ${ }^{12)}$ は Basal uptake 及び Insulin effect に有意差を認めないと云つ ている。体重に関しては，Willebrands $\left.{ }^{14}\right)$ の幼若白鼠が Sensitivity が良いと云ている事より，標本作製に必 要な成長度と考元合わせて $120 \mathrm{~g}$ 前後とした，尚体重を一定にする事は，横隔膜標本の表面積，厚さ，重量 等を，更には Medium 中に於ける代謝表面積或は酸素供給を一定にする為にも当然の事である.

次に使用ラットの飼育条件に依る横隔膜の Insulin effect の中, 飼料の影響については云うまでもなく, 糖質, 脂質, 蛋白質の三大栄養素が大きな役割を持ち, それに関しては, Gilmore and Samuels ${ }^{25)}$, Hansen et $\mathrm{al}^{21)}$, Lundbaeck and Stevesen ${ }^{26)}$, 等の報告があるが, Kerly and Ottaway ${ }^{24)}$ は特にての三栄養素の割合を種 
Table 2 (B) Influence of the added Insulin upon $\mathrm{QO}_{2}$ of rat diaphragm

(Medium : 200mg/dl sugar-phosphate buffer solution with variety conc. of insulin)

\begin{tabular}{c|c|c|c|c|c|c|c}
\hline \hline $\begin{array}{l}\text { conc. of added } \\
\text { Insulin u/cc }\end{array}$ & 0 & $10^{-5}$ & $10^{-4}$ & $10^{-3}$ & $10^{-2}$ & $10^{-1}$ & $10^{\circ}$ \\
\hline & 6.22 & 6.78 & 6.09 & 5.98 & 6.75 & 6.71 & 6.71 \\
& 7.51 & 7.01 & 6.03 & 6.24 & 5.96 & 5.73 & 6.14 \\
& 6.10 & 6.99 & 6.58 & 7.10 & 5.81 & 5.81 & 6.68 \\
& 6.48 & 5.76 & 6.74 & 7.01 & 6.26 & 7.06 & 6.61 \\
& 6.37 & 6.55 & 5.76 & 6.23 & 5.83 & 6.92 & 7.21 \\
& 5.89 & 6.01 & 6.64 & 5.98 & 7.32 & 6.11 & 7.01 \\
& 5.87 & 6.21 & 5.19 & 6.88 & 7.21 & 6.03 & 6.86 \\
& 6.19 & 5.39 & 6.22 & 6.35 & 5.99 & 5.36 & 5.39 \\
& 6.60 & 7.01 & 6.10 & 6.81 & 6.41 & 5.91 & 5.96 \\
& 5.40 & 6.21 & 6.98 & 6.59 & 6.86 & 5.84 & 7.48 \\
& 7.09 & 5.96 & 6.50 & 5.84 & 7.02 & 6.36 & 5.92 \\
& 6.76 & 5.83 & 6.19 & 6.36 & 6.03 & 7.04 & 6.31 \\
& 6.30 & 6.06 & 6.77 & 6.16 & 5.84 & 7.10 & 6.66 \\
& 5.51 & 6.31 & 5.86 & 6.07 & 6.22 & 6.84 & 6.18 \\
& 6.21 & 5.99 & 5.21 & & 6.23 & 6.91 & 5.24 \\
& & 6.87 & 7.01 & & 7.03 & & 6.01 \\
\hline standard & 6.53 & 0.47 & 0.50 & 0.39 & 0.55 & 0.54 & 0.60 \\
\hline \multirow{2}{*}{ Aveviation } & 6.40 & & & 5.36 & & \\
\hline
\end{tabular}

々変えた飼料を用い，基礎実験を行つているが，之等の実験成績より云える事は，高糖質食では Basal uptake が高值を示し，高脂肪食，高蛋白食では Basal uptake, Insulin effect 共に変動する事である。乙の変 動については增大或は減少と一定しないが，結論的には著者の如く各栄養素の平衡を保つた Oriental 固型 飼料を使用するのが，最む安定した結果を得るのに容易である。高脂肪食, 高蛋白食に於て, 各研究者の成 績が一定していない事は，横隔膜の Glucose uptake に直接影響を及ばすので無く，横隔膜の筋細胞の代謝 全体に影響を与え，その 2 次的な結果であると思われる。乙の間の事情は，同時に起る酸素消費量の消長， 及 Acetate, Pyruvate を基質として用いた場合の実験成績に徴しても充分うなずける事であり，飼料の組成 の影饗は, Insulin effect よりもむしろ Basal uptake に及ぶあのであると思われる ${ }^{15}$. ラット環境飼育温 度の条件と飼料組成の問题との組合せについて.同一条件に於て飼育されたラットの横隔膜の Basal uptake と Insulin effect とは一定範团内で反比例する ${ }^{24}$. 著者も Oriental 固型飼料, 自由雑食, 環境温度の邀い 等に於ける場合の Basal uptake 及び Insulin effect の垐違について同様の経駼を持つている. 環境温度に ついては, 各一定温度で得られる相関直線は夫々略々灭行之見做す事が出来る ${ }^{15)}$. 唯 $17^{\circ} \mathrm{C}$ 以上の温度の場合 とそれ以下の場合とではラットの代謝の様相に全然異つたものが現われると云うので'12)，17ํㅡㄴ下にならぬ

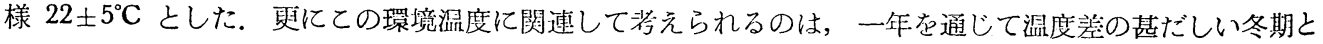
夏期に於て，ての Insulin effectは如何なる影響を受けるかの問題であるが， $22 \pm 5^{\circ} \mathrm{C}$ の条件下に於て室温 に放置出来るのは，著者の研究室では 4～6月，9～10月（之あ厳密に云えば春秋に於ける生体の代謝状況 は異るが）で11〜3 月は保温を要すが，人工的には簡単に 9 月より翌年 6 月位の間はこの条件下に於て実験 
が出来る訳である．馬場等 ${ }^{28}$ 亿依れば糖利用率に対する季節的影響は，夏期の方が冬期より高くなると云つ ているが，著者は夏期の（6９月）実験は行つていない. 夏期，冬期に於ける利用率の差違は，個体の全 代謝或はホルモン調節の終結像を示していると考えられる. Colowick, Cori and Slein ${ }^{29}$ はホルモンが組織の Hexokinase の Activity に直接影響するかす知れない事を指摘し，ての Hexokinase は crude pituitary extracts 亿依つて抑制され，更に副腎皮質抽出物に依つてとの抑制作用は増加されると報告した。 又 Park ${ }^{30}$ ， Villee and Hastings ${ }^{31)}$ はラット横隔膜の糖利用は下垂体摘出に依り促進され更に下垂体抽出物注射に依り抑

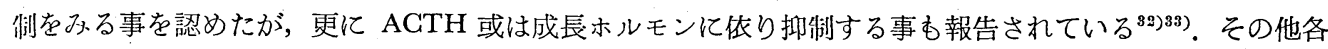
種ホルモンに依り横隔膜の 糖代謝に種々影響のある事が実証されているが，要するに夏期冬期の 差違には ホルモン調節状態が重大な関連性を持つ之考えられ，此の種の実験は比較的短期間内に同一条件，同一環境 下に実施する事が最良の基本的条件となるであろう，以上使用ラットの種類，成長度，性別，飼育条件につ いで, Kerly and Ottaway ${ }^{24)}$ ，Stadie and Zapp ${ }^{4)}$ は使用前の絶食時間价つても検討を加えている．乙の点 に関しても，各研究者により成績を異にしているが，初めから持つている糖原量と Insulin effect との関

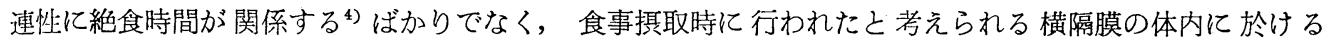
Insulinization の程度を屯考慮に入れなければならぬと思われるので，乙の相互に相反する条件のどちらか が表面に現われて来るかに依つているすのであろうと考えている．従つて絶食時間について Basal uptake， Insulin effect がどの様な変化が起るにせよ，何等かの影響を受ける事は確かであるから 12〜24 時間の絶食 洔間は㛜守されねばならぬ ${ }^{15}$. この点からあ著者の15時間は妥当である。

次に以上の諸問題以上に Glucose uptake, Insulin effect に影響を及ぼす実験手技について若干考察を加 える. 先ず最初に横隔膜標本の作り方であるが，之に関しては Gemmill et al ${ }^{54)}$ Gey and Gey ${ }^{35)}$, Stadie and Zapp ${ }^{4}$ 等は Single method を即ち横隔膜を二分し, 一つは Incubate 前の, 一つは Incubate 後の糖 原显を測定し，その前後の差が Insulin 添加により增加する事を利用する方法を採用した。，一方 Willebrands et $\mathrm{al}^{18)}$ 或は Permutter et $\mathrm{al}^{6)}$ は Pooled method を, 即ち一つは Insulin を含有しない, 一つは Insulin を含有せる Medium 中に Incubate し，その前後の横隔膜が uptake せる Glucose 量を測定し， Insulin を添加せる場合の Glucose uptake が促進せられる事を利用する方法を採用した，両者何れを選択 するかについては，(1)定量指標としてどちらが動摇の少ない測定值が得られるか. (2) Insulin は組織内へ葡 苮煻を掑取せしめるのか，或は掑取せる葡萄糖を組織内に於て糖原に合成する機転を促進させるのか，即ち Insulin の本質的な作用は何処にあるか等の問題が起つて来る ${ }^{15}$.

(1亿関しては，動物の個体差を眇くする事及び糖原定量法の信頼度之葡菊糖定量法の信頼度などより

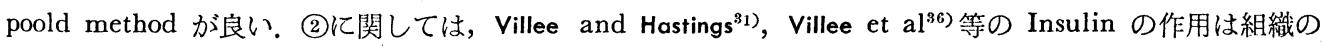
糖掑取の速度を增加させるものであると言う事よりも Pooled method を可とする。勿論筋糖利用能と糖原 合成は或程度平衡するすのであり, Walaas and Walaas ${ }^{37)} は$ Basal uptake の約75\%の糖原合成量を認め, Insulin を添加した洔には，Insulin effect に略々匹敵する Extraglycogen Synthesis を証明している，従 つて糖原合成量を定量指標とする事す本質的には否定出来ない. 又 Poold method には Hemidiaphragm 沚之 Quartardiaphragm 法がある7》。この両者の可否を論ずるに当つては，先ず同一の横隔膜であ部分差

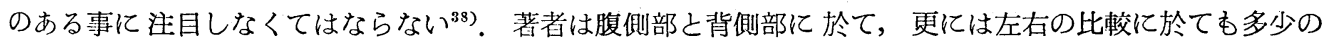
差㦀のある事を見出し，又4 分法が 2 分法に比べて 能率の高い為あえて 4 分法を採用したが， 4 分法で得 られる Insulin effect は2 分法に比べて絶刘值が低い場合あある22)ので実際には何れであ良いと思われ る. 次い Incubation でに移る訳であるが，ての時の条件で問題てなるのは，Medium の種類或はその $\mathrm{pH}$, 糖濃度, 更には Incubation time, 使用ガス等が主なむのである，従来 Medium として使用されて いるのは, Phosphate buffer と Bicarbonate buffer である. 何れを取るかについては, 従来採用されて いるのを見るに，両者の何れかを使用しているが，交献的にあ半々位で，ての条件により特に著明な差違は 無い椂である。，之はむしろ $\mathrm{pH}$ 亿重大な意味を持つ之思われる。著者は $\mathrm{pH} 7.4$ としたが，之は体液の $\mathrm{pH}$

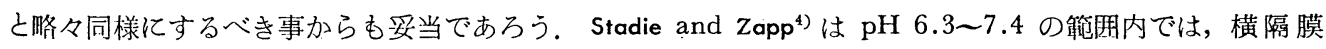


の糖原合成能及び Insulin 促進能と变化が見られなかつたとしている. 一方竹内 ${ }^{13}$ は Stadie と同じ Pho. sphate buffer にて pH を酸性にすると Basal uptake 亿殆んど変化が見られないのに反し, Insulin effect は次第に減少して行く傾向を示し，殊に $\mathrm{pH} 7.0$ 以下に於ては相当著しい抑制を見， $\mathrm{pH}$ がアルカリ側に 傾く時は Glucose uptake に大きな変化は見られないと云つている。辻もとの点に関し，initial pH 7.45 を中心に酸性側及びアルカリ性側の Medium は何れす Incubation 後には $\mathrm{pH} 7.45$ 亿近づき, $\mathrm{pH} 7.45$ 附近では変動は少ない，又 initial 6.1 7.3 の間では Medium か酸性化する程 Glucose uptake は徳くな

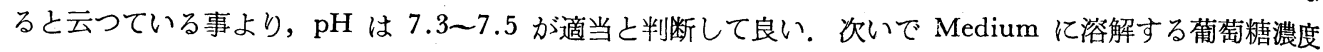
の選択に関しては, Stadie and Zapp $\left.{ }^{4}\right)$ て依れば $0.1 〜 1.0 \% の$ 範囲内に於ては横隔膜の糖原合成能に現われ る Insulin の促進能は一定であつたとしている. Krahl and Cori ${ }^{229}$ は0.1\%より0.2\%の場合が Basal uptake, Insulin effect 共に大であると云つているが，Basal uptake, Insulin effect 共に最大である濃度，即ち最大 公約数的な併む安定せる成績が得られる浱度が理想である. Soskin and Levine ${ }^{40)}$ は葡葡糖濃度が極めて高い 環境に於ては Insulin の作用が殆んど現われないと云つているし, Hechter et $\mathrm{al}^{(1)}$ は $0.1 \%$ 亿於ける Insulin effect は $0.4 \%$ 亿於ける略々 3 倍に達した。 即ち葡萄糖濃度が高くなるにつれて, 糖原合成能に及ばす Insulin effect は減少すると云つている. 竹内 ${ }^{15)} は 0.1$ 0.3\%の間で適当な濃度を選択するのが妥当であろ うと述へ，0.2\%を採用している．著者はかかる検討を行つていないが横隔膜の組織呼吸が 0.1〜0.5\%の間 に於て， $0.2 \%$ で最も增加を見た事からむ $0.2 \%$ が一番適当な浱度である事の何すのかを暗示している様に思 う. 更に横隔膜の Incubation time に関しては，Groen et $\mathrm{al}^{7)}$ は最も安定した Insulin effect を得る為に は90〜120 分としており，竹内 ${ }^{15}$ あ文 90 分以上の Incubation time が必要であろうと云つている。著者の 経験では60分以下に於て Insulin effect あ不安定である事を認めたが60 90分で殆んど安定して来る事を知 り，75分を Incubation time とした．之は短時間内では横隔膜の反応速度がまちまちである為で，60分以 上になれば，夫々の反応が終りに近ずくものと考える。辻等 ${ }^{399}$ むncubation time は 60〜90分としている し，ての時間で充分目的は達成出来るあのと思う. Incubation に際し，充媜するガスは, 教室で従来組織 呼吸用に使用して来た95１00\%の $\mathrm{O}_{2}$ を使用し，乙の $\mathrm{O}_{2}$ の消費量測定により，Medium 中の横隔膜の 反応が允分行われているか否かの一指標とした，以上簡単乍ら横隔膜法実施にあたり，著者の規定せる測定 条件を述へて来たが， その結果得られた実験成績即ち Insulin effect に対する Insulin 作用濃度標準直線

Fig. 3 Variability of the Concentration Action Curve of the Quantitative Effect of Insulin upon the Glucose Utilization of the Isolated Rat Diaphragm. Groen, Kamminga, Willebrands and Blickman : J. Clin. Invest, $31: 98,1952$

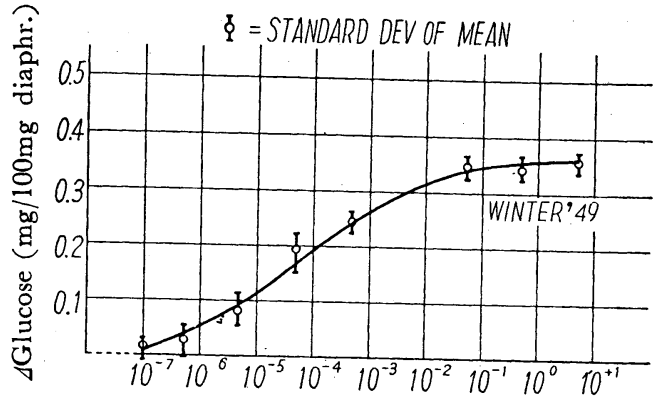

Conc. of Insulin (units/ml)
Fig. 4 The effect of increasing concentrations of insulin upon the glucose utilization of the isolated rat diaphragm expressed as a log-dose (of insulin) response curve. Randle : Brit Med. J. 1 : 1238, 1954

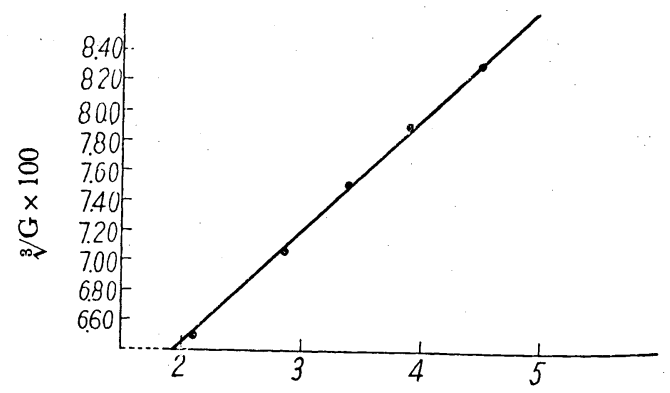

log. Insulin conc. Microunits $/ \mathrm{ml}$ 
について検討を加えよう. ラット横隔膜法に依 る Insulin の作用濃度曲線は Groen et $\mathrm{al}^{7}$, Randle $^{8)}$, 竹内 et $\mathrm{al}^{42}$ 等を始め多くの報告を 見るが，その曲線の性質は種々様々である(第 3 図, 第 4 図, 第 5 図).

直線回帰を証明すべきメタメーターも Groen et $\mathrm{al}^{7)}$, 竹内他 ${ }^{42)}$ 等は, Insulin effect と Ins ulin の対数濃度に, Randle ${ }^{8)}$ は Insulin effect の立方根と Insulin の対数濃度に, 著者は Insulin effect の対数及び Insulin の対数濃度と の間に於て証明している。この理由は著者にも 解らないが, 各研究者の実験操作上の違いが原 因するのでは無いかと思う，何れにしろ著者は 自分の成績を最む信じ以下実験を行つたあので ある. 勿論前述の Insulin 作用濃度標準直線 を元に血墏中の Insulin 量測定も行つたが，然 らば血漿の示す Juptake が果して血獎中の Insulin に侬るあのか否か. 又 Insulin 飞依るあのとしても，それ以外の物質即ち， Insulin 様作用物質 (Glucose uptake 促進物質) 或は抗 Insulin 様作用物質 (Glucose uptake 阻害物質) が存在しないか等, 重大な問題が残されている，血漿の示す Juptake が血漿中の Insulin に依るものであるとする論拠は,

a）正常犬の血漿で認められた Glucose uptake 促進作用は膵剔犬血奬では殆んど或は全く認められない.

Table 3 Promotion of Glucose uptake by serum

\begin{tabular}{|c|c|c|c|c|c|c|c|c|}
\hline Medium & $\begin{array}{l}\text { Flask } \\
\text { Number }\end{array}$ & $\begin{array}{l}\text { Number of } \\
\text { Quartar- } \\
\text { diaphragm } \\
\text { alone }\end{array}$ & $\begin{array}{l}\text { glucose conc. } \\
\text { before Incu- } \\
\text { bation } \\
(\mathrm{mg} / \mathrm{dl})\end{array}$ & $\begin{array}{l}\text { glucose conc. } \\
\text { after Incub- } \\
\text { ation } \\
\quad(\mathrm{mg} / \mathrm{dl})\end{array}$ & $\begin{array}{l}\text { glucose } \\
\text { uptake } \\
(\mathrm{mg} / \mathrm{dl})\end{array}$ & $\begin{array}{l}\text { dry weight } \\
\text { of Quarta- } \\
\text { rdiaphragm } \\
\text { alone } \\
\quad(\mathrm{mg})\end{array}$ & $\mathrm{QO}_{2}$ & $\begin{array}{l}\text { glucose uptake } \\
\text { /lgr. dry we- } \\
\text { ight diaphr. } \\
\text { (mg/dl/gr.) }\end{array}$ \\
\hline \multirow{5}{*}{ 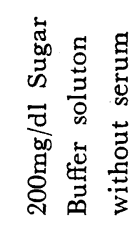 } & 1 & $\mathrm{~A}_{1}$ & 201 & 190 & 11 & 10.56 & 6.32 & 20.82 \\
\hline & 2 & $\mathrm{~B}_{2}$ & 200 & 189 & 11 & 9.83 & 7.01 & 22.38 \\
\hline & 3 & $\mathrm{C}_{3}$ & 201 & 186 & 15 & 13.53 & 7.04 & 22.18 \\
\hline & 4 & $\mathrm{D}_{4}$ & 199 & 187 & 12 & 10.96 & 6.87 & 21.89 \\
\hline & \multicolumn{4}{|c|}{ Average } & \multicolumn{2}{|c|}{ (Basal uptake) } & 6.81 & 21.82 \\
\hline \multirow{5}{*}{ 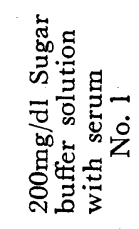 } & 5 & $\mathrm{~A}_{4}$ & 201 & 186 & 15 & 13.03 & 7.98 & 23.04 \\
\hline & 6 & $\mathrm{~B}_{1}$ & 199 & 184 & 15 & 11.58 & 8.96 & 25.90 \\
\hline & 7 & $\mathrm{C}_{2}$ & 198 & 182 & 16 & 13.11 & 8.63 & 24.40 \\
\hline & 8 & $\mathrm{D}_{3}$ & 202 & 188 & 14 & 11.35 & 8.21 & 24.66 \\
\hline & \multicolumn{6}{|c|}{ Average } & 8.45 & 24.50 \\
\hline \multirow{5}{*}{ 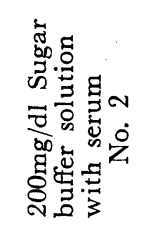 } & 9 & $\mathrm{~A}_{3}$ & 202 & 188 & 14 & 11.24 & 8.32 & 24.90 \\
\hline & 10 & $\mathrm{~B}_{4}$ & 204 & 190 & 14 & 11.03 & 8.91 & 25.38 \\
\hline & 11 & $\mathrm{C}_{1}$ & 198 & 183 & 15 & 11.17 & 8.36 & 26.84 \\
\hline & 12 & $\mathrm{D}_{2}$ & 199 & 186 & 13 & 11.05 & 8.04 & 23.52 \\
\hline & \multicolumn{6}{|c|}{ Average } & 8.41 & 25.16 \\
\hline
\end{tabular}


（第 2 章，第 2 節）との事は Groen et $\mathrm{al}^{7}$ ) も認めている.

b) 正常体に Insulin を注射すると短時間の間，血漿中の Glucose uptake 促進作用は増大する事を Vallance-Owen et $\mathrm{al}^{10)}{ }^{43}$ は報告しているが，著者も正常体に Insulin 筋注後約30分に Glucose uptake が 増大し，との増大せる Juptake 相当值の Insulin 量は，之に循環血液量を乗ずると大略投与量に近いむの になる (第 3 章第 2 節).

c）稀釈血漿が Insulin 溶液と同様 Glucose uptake を促進させると同時に ADHR ラットの血糖降下 作用を有する。

d) 自発性低血糖症の場合 (Vallance-Owen et $\mathrm{al}^{45}$ ) Insuloma の場合 (Kelly ${ }^{44)}$ ) には Insulin 効果は強 く手術により剔出すると弱くなる，又 Insulin Mangel Diabetes の血槳は Insulin 效果が弱い事を著者は 経験している。

e ）Bioassay の一般に於て行われている Similary test を標準 Insulin 溶液と稀釈血漿を用いて実施す る之，両者の間には平行関係が成立する (Randle ${ }^{8}$ ) 竹内 et $\mathrm{al}^{15)}$ ).

以上血漿の示す Suptake が血獎中の Insulin に依ると云う論拠であるが， 反面 Park ${ }^{46)}$ ，Bornstein and Park $^{47)}$, Bornstein ${ }^{48)}$ 等は血漿中の Insulin 量とは無関係であるとしているし, Park and Krahl ${ }^{49)}, O_{\text {Otraway }}{ }^{50}$ 51) は Growthhormon に Insulin 様作用があると報告しているが最近 Randle and Young ${ }^{52)}$ はを否定し ている，辻等 ${ }^{32}$ は内分泌ホルモンについて検討を加え，ACTH は極く僅かではあるが Insulin 様作用を認 め, Growth hormon は Insulin 様作用に拮抗すると云つている。又先に述べた $\Delta$ uptake が血中の Insulin 量と無関係である理由の一つとして, Bornstein は Glucose uptake 阻害因子が血漿蛋白分劃中 $\beta$-Lipoprotein 一恐らくこれは脳下垂体から分泌されると目されるが (Bornstein and $\mathrm{Krah}^{53}$ ) 一が存在し，之を 除去しなくてはならぬとしている，以上定説は見あたらないが，何れにしろ内分泌脉ホルモン及び血漿蛋白 分劃中の特に $\beta$-Lipoprotein などは Glucose uptake に重大な関係を持つ様に思われるが，今後の検討に

Table 4 各種操作条件によるラット横隔膜標本の糖捸取能及び酸素消費能の変化傾向（竹内）

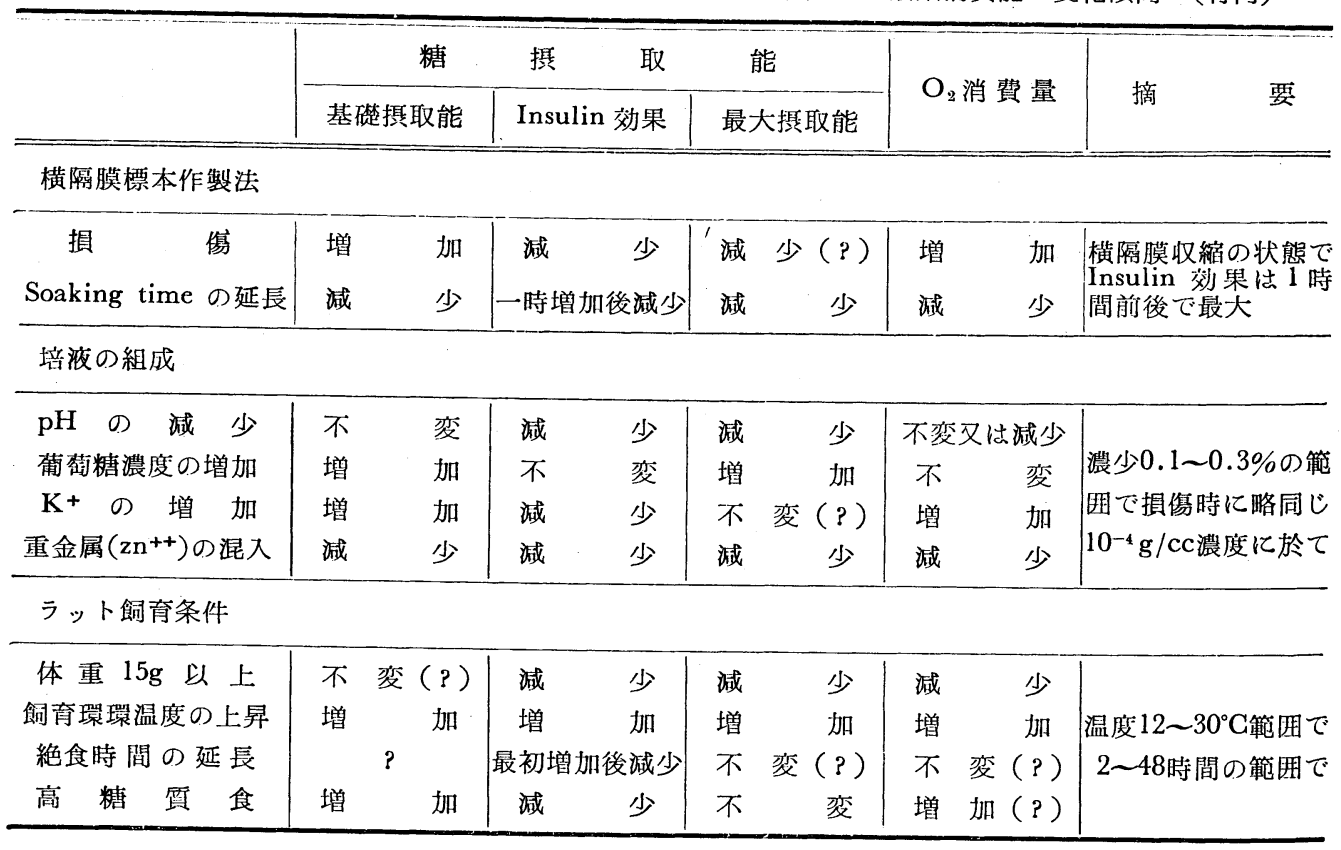

? 印は一定の傾向を示さないか, 一定の傾向を有しているらしいが有意の変化と判定し難い場合 
待ちたい.

最後に同時に測定せる横隔膜の酸素消費量との関係については，著者は QO 2 を実験成績に加え，Flask 内に於ける横隔膜の Glucose uptake の一指標とした。組織呼吸に有意の差を認めた場合は，第 4 表 ${ }^{15}$ の 何れかに相当し，実験条件に重大な相違を来したものと推察し，実験成績より除外する事にした。 $\mathrm{QO}_{2} は$ 実験成績の如くInsulin により影響を受ける事は殆んどない。之は Gemmill ${ }^{234)}$ 亿依り既に広く知られた事. 実である，尚時として理由不明のまま可成り飛び離れた成績を見る事があり，実験成績より除外せざるを得 なかつた事を附記する。

\section{第二章 血中 Insulin 量測定值}

\section{第 1 節 実験対照及ひ実験方法}

実験対照は健康者，糖尿病患者，正常家鬼，Alloxan 家鬼，正常犬及び除膵大とし，夫々の空腹時血中 Insulin 量及び血糖值を測定比較した。実験方法は人間に於ては早朝空腹時に肘静脈より採血し，家鬼は耳 神経，交感神経を予め切断しておいて，空腹時に耳静脈より採血した。 Alloxan 家曱は，Eastman-Codak 社製 Alloxan-Monohydrate 170 200mg/kg を静注， 糖尿病を発症せしぬ 5 日以後のむのを実験に供し

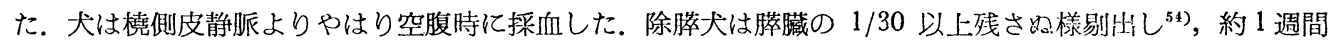
後に実験に供した。，その間食飼は雑食にしたが，パンクレアチンを之に混じ与えた，採血した血液には極く 少量の弗化ソーダを加え, 還心血漿を分離し, 得られた血漿について, 血糖は Hagedorn-Jensen 氏法にて, Insulin 量はラット横隔膜法にて測定した.

\section{第 2 節 測定成績}

\section{1）正常人及び糖尿病患者}

Table 5 Insulin amounts of normal human blood and blood sugar levels

\begin{tabular}{|c|c|c|c|c|c|c|}
\hline No. & name & age & $\operatorname{sex}$ & $\begin{array}{c}\text { body weight } \\
(\mathrm{kg})\end{array}$ & $\begin{array}{l}\text { blood sugar } \\
\text { level } \\
\text { (mg/dl) }\end{array}$ & $\begin{array}{l}\text { serum } \\
\text { Insulin } \\
\text { (mu/cc) }\end{array}$ \\
\hline 1 & H.S. & 26 & 占 & 50.1 & 100 & U. 27 \\
\hline 2 & K.O. & 29 & 今 & 60.5 & 108 & 0.42 \\
\hline 3 & M. I. & 30 & $\hat{o}$ & 78.0 & 92 & 0.40 \\
\hline 4 & S.N. & 21 & 우 & 54.5 & 90 & 0.26 \\
\hline 5 & H.K. & 24 & 우 & 50.1 & 80 & 0.38 \\
\hline 6 & M. I. & 32 & $\hat{o}$ & 61.0 & 98 & 0.258 \\
\hline \multicolumn{5}{|c|}{ Average } & 95 & 0.338 \\
\hline
\end{tabular}

第 5 表は 6 例の健康者早朝空腹時血糖值及び血中 Insulin 量である。血糖値は 80〜 103 rag/dl, 平均 95 $\mathrm{mg} / \mathrm{dl}$, 血中 Insulin 量は $0.26 \sim 0.42 \mathrm{mu} / \mathrm{cc}$ 平均 $0.338 \mathrm{mu} / \mathrm{cc}$ であつた。（第 1 例は怪度の甲状腺腫を 衿めたが，自他覚的症状殆んど無く，単純性甲状腺腫で，第 3 章の実験に於ても健康老と同様の成績を示し た例である。）第 6 表は糖尿病㭧者の早朝空腹時血糖㒹及び血中 Insulin 量である. 測定当時未治療の者, 治療中の者等まちまちであるが，治療中の考は（Insulin 又は抗糖尿病剂） 3 ～5 日前より治療を中止して 测定した.

10例の血糖値は $128 \sim 241 \mathrm{mg} / \mathrm{dl}$, 平均 $193 \mathrm{mg} / \mathrm{dl}$, 血中 Insulin 量は $0.01 \sim 0.24 \mathrm{mu} / \mathrm{cc}$ 平均 $0.12 \mathrm{mu}$ /cc であり健康者に比べて低值を示した。乙の中第 1 例, 第 2 例は共に Insulin 耐性を示すすのであるが, (両者共約 6 力月間 Regular Insulin 40〜50 unit/day 投与されていた) $0.08 \mathrm{mu} / \mathrm{cc}$ と極めて低値であつ 
Table 6 Insulin amounts of diabetics blood and blood sugar levels

\begin{tabular}{|c|c|c|c|c|c|c|c|c|}
\hline No. & name & age & $\operatorname{sex}$ & $\begin{array}{l}\text { body } \\
\text { weight } \\
(\mathrm{kg})\end{array}$ & $\begin{array}{l}\text { blood sugar } \\
\text { leyel } \\
(\mathrm{mg} / \mathrm{dl})\end{array}$ & $\begin{array}{l}\text { serum } \\
\text { Insulin } \\
(\mathrm{mu} / \mathrm{cc})\end{array}$ & $\begin{array}{l}\text { complica- } \\
\text { tion }\end{array}$ & urine sugar \\
\hline 1 & U.S. & 41 & 우 & 45.5 & 241 & 0.08 & \multirow{3}{*}{$\begin{array}{l}\text { high blood } \\
\text { pressure } \\
\text { nephrose } \\
\text { neuralgia }\end{array}$} & $(+)$ \\
\hline 2 & H.K. & 52 & $\hat{\delta}$ & 52.0 & 240 & 0.08 & & $50 \sim 70 \mathrm{~g} /$ day \\
\hline 3 & M.M. & & 우 & 51.0 & 236 & 0.13 & & $(+)$ \\
\hline 4 & $\mathrm{~S} . \mathrm{K}$. & 55 & $\hat{\delta}$ & 50.5 & 222 & 0.01 & \multirow[t]{3}{*}{$\begin{array}{l}\text { heart } \\
\text { disease }\end{array}$} & $80 \sim 100 \mathrm{~g} / \mathrm{day}$ \\
\hline 5 & A.Y. & & 우 & 49.1 & 209 & 0.192 & & $(+)$ \\
\hline 6 & E.H. & 40 & 우 & 56.5 & 209 & 0.128 & & $1 \sim 10 \mathrm{~g} /$ day \\
\hline 7 & S.K. & 55 & & 50.5 & 161 & 0.10 & \multirow[t]{2}{*}{$\begin{array}{l}\text { heart } \\
\text { disease }\end{array}$} & $5 \sim 10 \mathrm{~g} / \mathrm{day}$ \\
\hline 8 & F.H. & 20 & 우 & 48.0 & 144 & 0.04 & & $0 \sim 5 \mathrm{~g} /$ day \\
\hline 9 & H. I. & 43 & 우 & & 143 & 0.17 & \multirow[b]{2}{*}{$\begin{array}{l}\text { high blood } \\
\text { pressure } \\
\text { nephritis }\end{array}$} & $(+)$ \\
\hline 10 & $\mathrm{~T} . \mathrm{K}$ & 48 & 今 & 52.0 & 128 & 0.24 & & $14 \sim 25 \mathrm{~g} / \mathrm{dl}$ \\
\hline \multicolumn{5}{|c|}{ Average } & 193 & 0.12 & & \\
\hline
\end{tabular}

た. 第 4 例，第 7 例は同一患者である，第 4 例は入院時, 治療前の測定成績であり，その 後 Insulin 治療により軽快した例である。入 院封の主訴口喝, 多食, 多尿, 全身倦急感等も 消失し，尿量 $1600 \sim 2200 \mathrm{cc} /$ day 尿糖80 100 g/day であつたのが尿量 $1200 \sim 1600 \mathrm{cc} / \mathrm{day}$ 尿糖 5〜 $10 \mathrm{~g} /$ day となり，血糖值は $222 \mathrm{mg}$ /dl より $161 \mathrm{mg} / \mathrm{dl}$ となつたものであるが’ この例に於ては, 糖尿病の改善と共に血 中 Insulin 量も $0.01 \mathrm{mu} / \mathrm{cc} よ り 0.1 \mathrm{mu} / \mathrm{cc}$ よ 10倍の増加を認めた. 又第 8 例は若年性の Insulin Mangel Diabetes と思われるあので あるが, Insulin 量は $0.04 \mathrm{mu} / \mathrm{cc}$ と低く, 治療によるも，血中 Insulin 量の増加を認 めなかつた. 第 3 例，第 5 例，第 6 例，第 9 例は治療に依り次第に症状及び血糖值の改善 されて行つた者である。

\section{2）正常家鬼及ひ Alloxan 家鬼}

第 7 表は正常家鬼の空腹時血中 Insulin 量及び血糖值である。10例の血糖値は 95〜106 mg/dl 平均 101 $\mathrm{mg} / \mathrm{dl}$ 血中 Insulin 量は $0.23 \sim 0.48 \mathrm{mu} / \mathrm{cc}$ 平均 $0.327 \mathrm{mu} / \mathrm{cc}$ であり, 人間の正常值と略々同様の値で ある. 一方 Allocan 家鬼の血中 Insulin 量及び血糖值は第 8 表に示す如くで， In糖值は 308〜 652 mg/dl 平均 $359 \mathrm{mg} / \mathrm{dl}$ で血中 Insulin 量は $0.01 \mathrm{mu} / \mathrm{cc}$ 以下が多く, 適確な測定は困難で, 第 1 例及び第 6 例に 於て夫々，0.02mu/cc，0.084mu/cc を認めたが，正常家象に比べて極度の減少を認めた.
Table 7 Insulin amounts of normal rabbit blood and blood sugar levels

\begin{tabular}{c|c|c|c}
\hline & $\begin{array}{c}\text { body } \\
\text { weight } \\
(\mathrm{kg})\end{array}$ & $\begin{array}{c}\text { blood sugar } \\
\text { level } \\
(\mathrm{mg} / \mathrm{dl})\end{array}$ & $\begin{array}{c}\text { serum Insulin } \\
(\mathrm{mu} / \mathrm{cc})\end{array}$ \\
\hline \hline 1 & 2.5 & 102 & 0.317 \\
2 & 2.6 & 106 & 0.48 \\
3 & 2.7 & 98 & 0.248 \\
4 & 2.6 & 105 & 0.23 \\
5 & 2.45 & 95 & 0.36 \\
6 & 3.1 & 98 & 0.36 \\
7 & 3.5 & 96 & 0.28 \\
8 & 2.9 & 104 & 0.29 \\
9 & 3.0 & 105 & 0.39 \\
10 & 2.8 & 102 & 0.315 \\
\hline \multicolumn{2}{l}{ Average } & 101 & 0.327 \\
\hline
\end{tabular}




\section{3) 正常犬及び除膵犬}

正常犬の 6 例の空腹時血糖値は第 9 表の如 $<75 \sim 98 \mathrm{mg} / \mathrm{dl}$ 平均 $81 \mathrm{mg} / \mathrm{dl}$, 血中 Insulin 量は $0.076 \sim 0.24 \mathrm{mu} / \mathrm{cc}$ 平均 $0.178 \mathrm{mu}$ /cc で正常人及び正常家兔より低值を示し た. 一方この 6 例の正常犬の愺藏剔出後約 1 週間に於ける測定成績は第10表の如く血糖值 は $198 \sim 330 \mathrm{mg} / \mathrm{dl}$ 平均 $278 \mathrm{mg} / \mathrm{dl}$, 血中 Insulinin 量は零乃至 $0.01 \mathrm{mu} / \mathrm{cc}$ 以下であ る. Insulin は殆んど或は全く認めない.

第 3 節 小括及び考按

以上正常体及び糖尿病体の血中 Insulin 量 を測定比較して, 前述の如き成績を得, 糖尿 病の本態である高血糖が血中 Insulin 量の 相対的欠乏にある事を，更にアロキサン家鬼 或は除膵犬に於ては血中 Insulin 量の絶対的 欠乏を来している事を認めた。

符11表は健常体の血中 Insulin 量を湘定し た諸家の成績である. 空腹時或は糖負荷後の 末枌血中 Insulin の濃度は各報告者に依り可 成りの相違があるが，in vivo の方法に依る 成績を通覧するに, 略々 $0.1 \sim 0.4 \mathrm{mu} / \mathrm{cc} の$ 間にある事がうなずける。一方ラット横隔膜 法に依る成績はまちまちであるが，之は測定 法の不備に依るものと考えられる。即ち近年 この方法が非常に敩密に規定された諸条件の もとに於て测定可能なの事より，それを提唱 した竹内等 ${ }^{13)}$ を始めそれに準じた，辻等 ${ }^{32}$ の 成績が略々信頼されるものと思う。即ち横隔 膜法に低る測定值は $0.1 〜 0.5 \mathrm{mu} / \mathrm{cc}$ のあた りにあり, 之等の成績より, 著者の成績も, 著者の測定法に従えば適確な欰中 Insulin 量 を現わしているもの之確信する。

一方糖尿病体の血中 Insulin 濃度は, 糖尿 病患者，アロキサン家鬼，除膵犬共々に正常 体より僅かに或は極度の低值を示したが，糖 尿病患者についての諸家の成績を通覧する に, Bornstein and Lawrence ${ }^{56) 57)}$ が下垂体, 副 筒剔出アロキサンラットを用いて，ブドウ糖 $50 \mathrm{~g}$ を経口投与し，2 時間後の未枌血槳中の Insulin 濃度を測定した 絬果に依れば，（彼 等の測定法に依れば，正常人空腹時血中 Insulin 濃度は $0.1 \mathrm{mu} / \mathrm{cc}$ で，それより低い糖
Table 8 Insulin amounts of alloxan rabbit blood and blood sugar levels

\begin{tabular}{c|c|c|c}
\hline \hline & $\begin{array}{c}\text { body } \\
\text { weight } \\
(\mathrm{kg})\end{array}$ & $\begin{array}{c}\text { blood sugar } \\
\text { level } \\
(\mathrm{mg} / \mathrm{dl})\end{array}$ & $\begin{array}{c}\text { serum Insulin } \\
(\mathrm{mu} / \mathrm{cc})\end{array}$ \\
\hline 1 & 2.5 & 380 & 0.02 \\
2 & 2.6 & 652 & 0 \\
3 & 3.2 & 416 & 0 \\
4 & 2.6 & 603 & $<0.01$ \\
5 & 3.1 & 351 & 0 \\
6 & 2.8 & 308 & 0 \\
7 & 3.4 & 352 & 0.084 \\
8 & 3.3 & 314 & $<0.01$ \\
\hline
\end{tabular}

Table 9 Insulin amounts of normal dog blood and blood sugar levels

\begin{tabular}{c|c|c|c}
\hline \hline No & $\begin{array}{c}\text { body } \\
\text { weight } \\
(\mathrm{kg})\end{array}$ & $\begin{array}{c}\text { blood sugar } \\
\text { level } \\
(\mathrm{mg} / \mathrm{dl})\end{array}$ & $\begin{array}{c}\text { serum Insulin } \\
\text { (mu/cc) }\end{array}$ \\
\hline 1 & 16.0 & 70 & 0.076 \\
2 & 16.5 & 75 & 0.192 \\
3 & 7.2 & 86 & 0.24 \\
4 & 7.5 & 81 & 0.20 \\
5 & 10.3 & 98 & 0.19 \\
6 & 11.6 & 75 & 0.17 \\
\hline
\end{tabular}

Table 10 Insulin amounts of depancreatized dog blood and blood sugar levels

\begin{tabular}{c|c|c|c}
\hline No & $\begin{array}{c}\text { body } \\
\text { weight } \\
(\mathrm{kg})\end{array}$ & $\begin{array}{c}\text { blood sugar } \\
\text { level } \\
(\mathrm{mg} / \mathrm{dl})\end{array}$ & $\begin{array}{c}\text { serum Insulin } \\
(\mathrm{mu} / \mathrm{cc})\end{array}$ \\
\hline \hline 1 & 16.0 & 292 & 0 \\
2 & 15.5 & 330 & 0 \\
3 & 7.0 & 198 & $<0.01$ \\
4 & 6.0 & 320 & $<0.01$ \\
5 & 8.1 & 231 & 0 \\
6 & 10.1 & 286 & $<0.01$ \\
\hline \multicolumn{2}{l}{ Average } & 278 & \\
\hline
\end{tabular}


Table 11 各研究者の健常体血中 Iusulin 量

\begin{tabular}{|c|c|c|c|c|c|}
\hline & 報 告 者 & 年 代 & 測 定 法 & 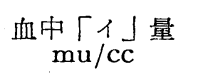 & 検 \\
\hline $\begin{array}{l}\stackrel{\circ}{\frac{2}{5}} \\
.\end{array}$ & $\begin{array}{l}\text { Allen et al } \\
\text { Gellhorn et al } \\
\text { Bornstein } \\
\text { Bornstein et al } \\
\text { 小 坂 他 }\end{array}$ & $\begin{array}{l}1941 \\
1941 \\
\\
1950 \\
1951 \\
1955\end{array}$ & $\begin{array}{l}\text { HAd } \\
\text { HAd } \\
\text { DHA } \\
\text { DHA } \\
\text { HAd }\end{array}$ & $\begin{array}{l}\text { ca } 0.1 \\
\text { ca } 0.2 \\
0.1 \\
0.1 \\
0.34 \\
0.2 \sim 0.3 \\
0.3 \sim 0.4 \\
<0.15\end{array}$ & 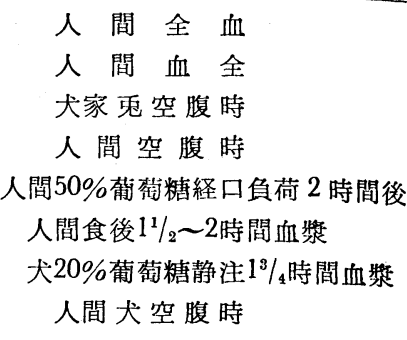 \\
\hline $\begin{array}{l}\stackrel{D}{5} \\
\text { 吾 } \\
. \Xi\end{array}$ & $\begin{array}{l}\text { Groen et al } \\
\text { Vallance-owen } \\
\text { Randle } \\
\text { 竹内 et al } \\
\text { 辻 et al }\end{array}$ & $\begin{array}{l}1952 \\
1954 \\
1954 \\
1956 \\
1958\end{array}$ & $\begin{array}{l}R D \\
R D \\
R D \\
R D \\
R D\end{array}$ & $\begin{array}{c}0.0625<<0.625 \\
0.01 \sim 0.08 \\
13.0 \\
0.12 \sim 0.24 \\
0.292 \sim 0.528\end{array}$ & 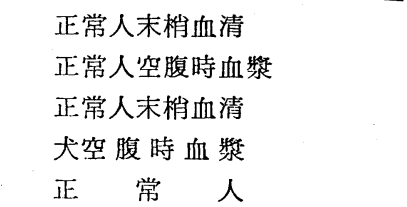 \\
\hline $\begin{array}{c}\mathrm{H} \\
\mathrm{A}\end{array}$ & $\begin{array}{l}\text { : 下垂体剔出 } \\
: \text { 副腎剔出 }\end{array}$ & & アロキ & 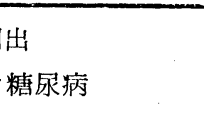 & \\
\hline
\end{tabular}

尿病患者の血中 Insulin 濃度は測定不能なる為, 葡葡糖を目荷後测定した) Ketosis を伴う15例の糖尿病患 者では血中 Insulin は全部零であり, Ketosis を伴わ妇13例の血中 Insulin 濃度は 0.1 0.32mu/cc 平均 $0.23 \mathrm{mu} / \mathrm{cc}$ であり, 対照 7 例平均 $0.34 \mathrm{mu} / \mathrm{cc}$ より低值を示した。尚 Insulin 零であつた例であ Insulin 治療により病状改善を見た 4 例では $0.20 〜 0.26 \mathrm{mu} / \mathrm{cc}$ 之血中 Insulin を証明出来る様になつたと云つて いる. 又 Groen et $\mathrm{al}^{7}$ ), Willebrands et $\mathrm{al}^{53}$ は横隔膜法依り Insulin で調節されている糖尿病患者の血清 中 Insulin activity は正常者と変りないが，糖尿病昏睡時には Insulin を認めなかつたと述べている事等 より，糖尿病患者の血中 Insulin 量は正常人より低い事は事実である，又逆に(著者は測定する機会を持た なかつたが) Willebrands et $\mathrm{al}^{\text {(5) }}$ は空腹時に低血糖ショックに陷つた既往歴のある15例の Hyperinsulinism の血漿 Insulin 濃度を出来るだけ発作中を選んで測定した。手術を受けた13例中11例にラ氏島腺腫を認めた

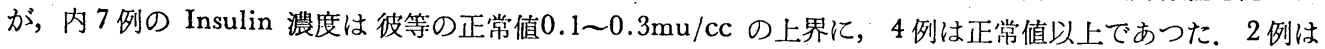
腺腫様組織を認めなかつたが，術後発作は消失し，ての 2 例の術前の Insulin 濃度は 5.0, 4.5mu/ccであ り，手術を受けなかつた 2 例は子供で $3.4,5.0 \mathrm{mu} / \mathrm{cc}$ 更にラ氏島癌の例では $3.6 \mathrm{mu} / \mathrm{cc}$ と夫々正常人よ りはるかに高值を示したと述へてている，小坂等(9)は肝転移を伴つた胃癌患者の自発性低血糖の発作中立びに ラ氏島腺腫を疑われた特発性低血糖症の空腹時に於ける末佾血漿の Insulin 量は（下垂体, 副腎髄啠剔出 ラットによる定量法）それぞれ $0.60 \mathrm{mu} / \mathrm{cc}, 0.75 \mathrm{mu} / \mathrm{cc}$ であり，健康者の $0.2 \mathrm{mu} / \mathrm{cc}$ 以下より極めて增 量していた。. 又 Kelly $y^{44)}$ は術前值 $0.3 \mathrm{mu} / \mathrm{cc}$ であつたラ氏鳥腙腫贯者が, 同腺腫剔出後 $0.05 \mathrm{mu} / \mathrm{cc}$ と減 少したと云つている. 尚彼の正常值は横隔膜法で 0.031 0.082mu/cc である. 我国で, 糖尿病患者の血中 Insulin 量が正常者より低いとするあのに峰下等 ${ }^{599}$, 山田等 ${ }^{(n)}$, などがあるが時には正常者と変らぬすのあ 浔めている. 勿論糖尿病の病型に依り異るであろう事は想像に難くないが, 著者の測定㑑の如く（僅か 1 例 に過ざないが），若年性の Insulin Mangel Diabetes と考光られるものに於ては Insulin 量の低下が殊に 著明なるのは当然であるが，老人性の Gegen Regulations Diabetes と考えられる者に於てあ血中 Insulin 量は低下しており，血中 Insulin 量の低下が，糖尿病の核心をなす高血糖慧起の一大原因たる事は否めな 
い. 又正常家鬼の血中 Insulin 量は $0.355 \pm 0.125 \mathrm{mu} / \mathrm{cc}$ で正常人と略々同じ濃度を示すが, Gellhorn et $\mathrm{al}^{61 \text { (12) }}$ に依れば（下垂体，副腎髄質剔出ラット法）ウサギの空腹時血中 Insulin 量は $0.1 \mathrm{mu} / \mathrm{cc}$ であり， 彼等の人間の血中 Insulin 量が食後 2 時間半で ca $0.2 \mathrm{mu} / \mathrm{cc}$ なる事より，人間と鬼の血中 Insulin 量は大 差ない様に見受けられる，次いで家鬼に Alloxan を静注する事に依り，ラ氏島の $\beta$ 細胞が選択的に破壊さ

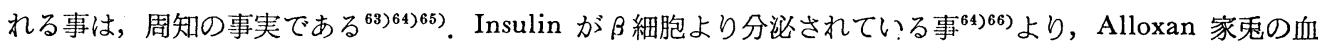
中 Insulin 量が激減している事は当然である. Alloxan 糖尿病の膵の Insulin 含有量については $2 \cdot 3$ の 報告がある. Goldner and Gomori ${ }^{67)}$ は 3 例の Alloxan 注射後18〜60日持続した糖尿病犬は，正常の $1 / 4$ に 減少していると云つている。 小坂等 ${ }^{68}$ は一過性の糖尿病犬では正常の $1 / 8$ に減少し，持続性糖尿病犬では 1/36に激減したと云つている。之等の事よりも血中 Insulin 量の減少は如何にも事実らしく考えられる所で あるが，著者は実際に血中 Insulin 量の城少を直接測定して証明した。更に正常犬の血中 Insulin 量は $0.158 \pm 0.082 \mathrm{mu} / \mathrm{cc}$ で正常人及び正常家鬼より低值を示したが，諸家の報告を見るに，Gellhorn et al ${ }^{61) 62)}$ （in Vivo）は鬼と同様 $0.1 \mathrm{mu} / \mathrm{cc}$ と云い，竹内 et $\mathrm{al}^{13}{ }^{3}$ （横隔膜法）は空腹時血漿 Insulin 量は0.12 0.24 $\mathrm{mu} / \mathrm{cc}$ であつたと云つている. 又小坂 ${ }^{69}$ は健康者 8 例及び正常犬 5 例の空腹時血漿 $1 \mathrm{cc}$ 中の Insulin 量は 下垂体副腎髄質剔出ラット法に依り測定出来なかつた，即ち $0.2 \mathrm{mu} / \mathrm{cc}$ 以下であつたと云つている. Waters and Best ${ }^{70)}$ が諸家膵剔犬に於ける実験成績より推論して，空腹犬の血中 Insulin 量はおよそ $0.5 \mathrm{mu} / \mathrm{cc} て ゙$ 種 々の条件を考え合わせると多分ての 1/2〜1/3 であろうとしたのは，著者の湘定值に大略一致している，一 方除膵犬については，Insulin 分泌の根源である膵を㓍んど剔出するのであるから，血中 Insulin 量む零或 はそれに近い成績を得たのむ当然であろう。

\section{第三章 Insnlin 負荷時に於ける血中 Imsulin 量の変動}

\section{第 1 節 実験対照及ひ実験方法}

実験対照は前章と同栐，実験方法は，人には Novo Regular Insulin 5２0 unit. 家鬼には 0.5〜2.5 unit $/ \mathrm{kg}$ 犬には 0.3 unit $/ \mathrm{kg}$ 筋注し，注射前及び注射後，30分，60分，120分，180分，240分後の血中 Insulin 量及び血糖值を前章と同様に測定比較した。

Table 12 Changes of insulin concentrations in circulating blood and blood sugar levels in each time $(30,60,120,180 \mathrm{~min})$ after i.m. injection of Novo Regular Insulin 5 units to normal human bodies.

\begin{tabular}{|c|c|c|c|c|c|c|c|c|c|c|}
\hline & \multirow{2}{*}{ name } & \multirow{2}{*}{$\operatorname{sex}$} & \multirow{2}{*}{ age } & \multirow{2}{*}{$\begin{array}{l}\text { body } \\
\text { weihgt } \\
(\mathrm{kg})\end{array}$} & & \multirow{2}{*}{$\begin{array}{l}\text { before } \\
\text { injection }\end{array}$} & \multicolumn{4}{|c|}{ after injection (min) } \\
\hline o. & & & & & & & 30 & 60 & 120 & 180 \\
\hline \multirow{2}{*}{1} & \multirow{2}{*}{ H. S. } & \multirow{2}{*}{$\hat{o}$} & \multirow{2}{*}{26} & \multirow{2}{*}{56} & Insulin & 0.27 & 1.10 & 1.00 & 0.68 & 0.48 \\
\hline & & & & & blood sugar & 100 & 75 & 71 & 86 & 108 \\
\hline \multirow{2}{*}{2} & \multirow{2}{*}{$\mathrm{K} . \mathrm{O}$. } & \multirow{2}{*}{$\hat{o}$} & \multirow{2}{*}{29} & \multirow{2}{*}{60} & Insulin & 0.40 & 2.10 & 0.68 & 0.19 & 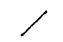 \\
\hline & & & & & blood sugar & 108 & 82 & 86 & 90 & $\zeta$ \\
\hline \multirow{2}{*}{3} & \multirow{2}{*}{ M. } & \multirow{2}{*}{ 㑒 } & \multirow{2}{*}{30} & \multirow{2}{*}{78} & Insulin & 0.40 & 1.14 & 1.04 & 0.60 & 0.40 \\
\hline & & & & & blood sugar & 92 & 68 & 79 & 83 & 83 \\
\hline \multirow{2}{*}{4} & \multirow{2}{*}{ S. N. } & \multirow{2}{*}{ 우 } & \multirow{2}{*}{22} & \multirow{2}{*}{55} & Insulin & 0.26 & 2.08 & 2.30 & 0.24 & 0.28 \\
\hline & & & & & blood sugar & 90 & 69 & 73 & 78 & 78 \\
\hline \multirow{2}{*}{\multicolumn{2}{|c|}{ Average }} & & & & insulin $(\mathrm{mu} / \mathrm{cc})$ & 0.33 & 1.61 & 1.25 & 0.43 & 0.39 \\
\hline & & & & & blood sugar $(\mathrm{mg} / \mathrm{dl})$ & 98 & 74 & 77 & 84 & 93 \\
\hline
\end{tabular}




\section{第 2 節 実験成績}

\section{1）正常者と糖尿病患者}

正常者に Novo Regular Insulin 5 unit 筋注した場合の 4 例の血中 Insulin 量及び血糖值の時間的変動 は第12表の如くである。乙の 4 例の平均值を見るに注射前の血中 Insulin 量は $0.33 \mathrm{mu} / \mathrm{cc}$, 血糖值は 98 $\mathrm{mg} / \mathrm{dl}$ であり, 注射 30 分後 $1.61 \mathrm{mu} / \mathrm{cc}, 74 \mathrm{mg} / \mathrm{dl}$ 60 分後 $1.25 \mathrm{mu} / \mathrm{cc}, 77 \mathrm{mg} / \mathrm{dl}, 120$ 分後 $0.43 \mathrm{mu} /$ $\mathrm{cc}, 84 \mathrm{mg} / \mathrm{dl}, 180$ 分後 $0.39 \mathrm{mu} / \mathrm{cc}, 93 \mathrm{mg} / \mathrm{dl}$ とな り, 血中 Insulin 量は注射後 30 分にして最高とな り，之は循環血液量と乗ずると注入量に近いすのと なる， 3 時間後に於て略々元に復し，血糖はそれに 従い減増する，之を図示すれば第 6 図の如くなる。 Insulin 5 unit 投与により平均血糖值は30分後に於 て $24 \mathrm{mg} / \mathrm{dl}$ の降下を見た。一方糖尿病患者に Insulin を注射した時の成續は第13，14表の如くで ある. 正常人之同様 Novo Regular Insulin 5 unit 笳注時に於ける血中 Insulin 量及び血糖值の变動 は13表の如く 4 例の平均值は注射前 $0.102 \mathrm{mu} / \mathrm{cc}$, $194 \mathrm{mg} / \mathrm{dl}$ で注射後 30 分では $1.80 \mathrm{mu} / \mathrm{cc}, 188 \mathrm{mg}$ /dl60分では $1.51 \mathrm{mu} / \mathrm{cc}, 169 \mathrm{mg} / \mathrm{d} 1120$ 分では 1.20 $\mathrm{mu} / \mathrm{cc}, 148 \mathrm{mg} / \mathrm{dl} 180$ 予では $0.67 \mathrm{mu} / \mathrm{cc}, 152 \mathrm{mg}$ /dl となり，之を図示すれば第 7 図の如くなる。又 10〜20 cmit 筋注した場合の成績は第14表の如くで ある. 5 例の血中 Insulin 量及び血糖值の平均值は

Fig. 6 Changes of insulin concentrations in circulating blood and blood sugar levels in each time after i.m. injection of Novo Regular Insulin 5 units to normal human bodies. Values are the average of four cases.

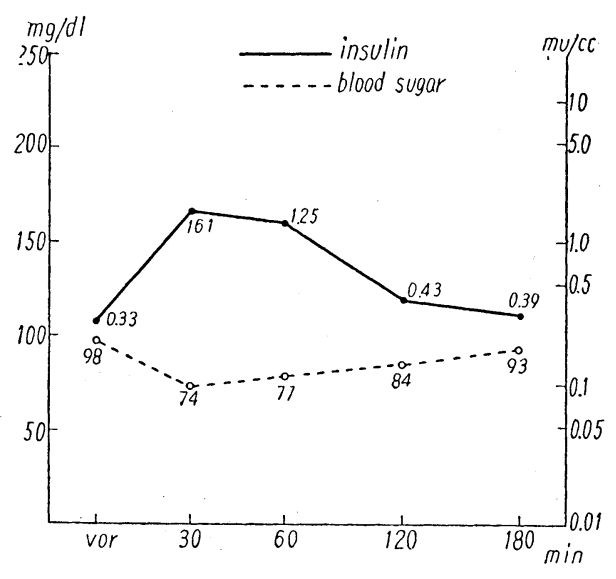

注射前 $0.10 \mathrm{mu} / \mathrm{cc}, 189 \mathrm{mg} / \mathrm{dl}$ で注射後 30 分では $4.26 \mathrm{mu} / \mathrm{cc}, 150 \mathrm{mg} / \mathrm{dl} 60$ 分後では $4.16 \mathrm{mu} / \mathrm{cc}, 104$

Table 13 Changes of insulin concentrations in circulating blood and blood sugar levels in each time $(30,60,120,180 \mathrm{~min})$ after i.m. injection of Novo Regular Insulin 5 units to diabetics.

\begin{tabular}{|c|c|c|c|c|c|c|c|c|c|c|}
\hline & \multirow{2}{*}{ name } & \multirow{2}{*}{$\operatorname{sex}$} & \multirow{2}{*}{ age } & \multirow{2}{*}{$\begin{array}{l}\text { body } \\
\text { weight } \\
\text { (kg) }\end{array}$} & & \multirow{2}{*}{$\begin{array}{l}\text { before } \\
\text { injection }\end{array}$} & \multicolumn{4}{|c|}{ after injection (min) } \\
\hline No. & & & & & & & 30 & 60 & 120 & 180 \\
\hline \multirow[t]{2}{*}{1} & \multirow[t]{2}{*}{ E. H. } & \multirow[t]{2}{*}{ 우 } & & \multirow{2}{*}{55.1} & insulin & 0.06 & 1.76 & 1.92 & 1.52 & 0.72 \\
\hline & & & & & blood sugar & 143 & 135 & 98 & 92 & 94 \\
\hline \multirow{2}{*}{2} & \multirow{2}{*}{ S. K. } & \multirow{2}{*}{$\hat{\delta}$} & \multirow{2}{*}{55} & \multirow{2}{*}{50.0} & insulin & 0.10 & 2.00 & 1.16 & 0.64 & 0.27 \\
\hline & & & & & blood sugar & 191 & 175 & 170 & 163 & 165 \\
\hline \multirow[t]{2}{*}{3} & \multirow{2}{*}{ M. M. } & \multirow{2}{*}{ 우 } & & \multirow{2}{*}{41.1} & insulin & 0.13 & 1.48 & 1.44 & 1.92 & 1.28 \\
\hline & & & & & blood sugar & 236 & 240 & 221 & 166 & 178 \\
\hline \multirow[t]{2}{*}{4} & \multirow{2}{*}{ K. T. } & \multirow{2}{*}{ 우 } & \multirow[t]{2}{*}{23} & \multirow{2}{*}{45.8} & insulin & 0.12 & 1.96 & 1.52 & 0.73 & 0.39 \\
\hline & & & & & blood sugar & 204 & 200 & 187 & 169 & 169 \\
\hline \multirow{2}{*}{\multicolumn{2}{|c|}{ Average }} & & & & insulin $(\mathrm{mu} / \mathrm{cc})$ & 0.102 & 1.80 & 1.51 & 1.20 & 0.67 \\
\hline & & & & & blood sugar $(\mathrm{mg} / \mathrm{dl})$ & 194 & 188 & 169 & 148 & 152 \\
\hline
\end{tabular}


Fig. 7 Changes of insulin concentration in circulating blood and blood sugar levels in each time after i.m. injection of Novo Regular Insulin 5 units to diabetics. Values are the average of four cases.

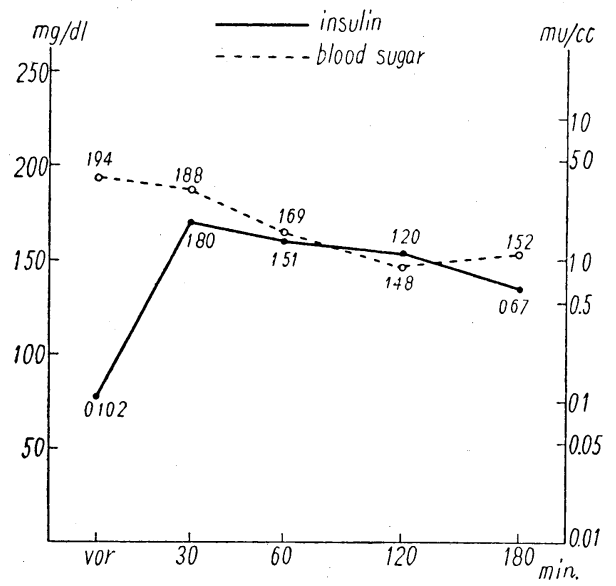

Fig. 8 Changes of insulin concentrations in circulating blood and blood sugar levels in each time after i.m. injection of Novo Regular Insulin 10 20 units to diabetics. Values are the average of five cases.

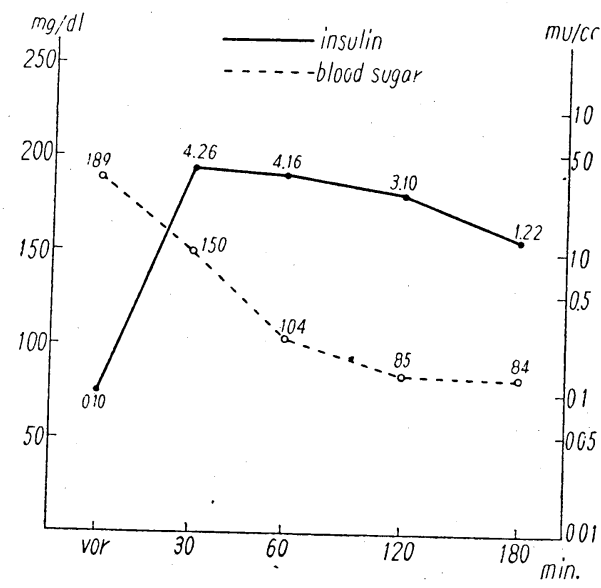

Table 14. Changes of insulin concentrations in circulating blood and blood sugar levels in each time after i.m. injection of Novo Regula Insulin 10 20 uinuts to diabetics.

\begin{tabular}{|c|c|c|c|c|c|c|c|c|c|c|}
\hline \multirow[b]{2}{*}{ No } & \multirow{2}{*}{ name } & \multirow{2}{*}{$\operatorname{sex}$} & \multirow{2}{*}{ age } & \multirow{2}{*}{$\begin{array}{c}\text { body } \\
\text { weight } \\
\text { (kg) }\end{array}$} & & \multirow{2}{*}{$\begin{array}{l}\text { before } \\
\text { injection }\end{array}$} & \multicolumn{4}{|c|}{ after injection $(\mathrm{min})$} \\
\hline & & & & & & & 30 & 60 & 120 & 180 \\
\hline \multirow{2}{*}{1} & \multirow{2}{*}{ T. $\mathrm{K}$. } & \multirow{2}{*}{$\hat{o}$} & & \multirow{2}{*}{50} & insulin & 0.24 & 4.00 & 2.80 & 2.84 & 1.20 \\
\hline & & & & & blood sugar & 128 & 116 & 96 & 72 & 54 \\
\hline \multirow{2}{*}{2} & \multirow{2}{*}{ F. H. } & \multirow{2}{*}{ 우 } & \multirow{2}{*}{20} & \multirow{2}{*}{48.0} & insulin & 0.04 & 1.52 & 6.00 & 2.72 & 1.04 \\
\hline & & & & & blood sugar & 144 & 113 & 78 & 84 & 84 \\
\hline \multirow{2}{*}{3} & \multirow{2}{*}{ E. $\mathrm{H}$. } & \multirow{2}{*}{ 우 } & \multirow{2}{*}{40} & \multirow{2}{*}{56.5} & insulin & 0.13 & 5.80 & 4.40 & 2.80 & 1.00 \\
\hline & & & & & blood sugar & 209 & 183 & 159 & 121 & 93 \\
\hline \multirow{2}{*}{4} & \multirow{2}{*}{ U. S. } & \multirow{2}{*}{ 우 } & \multirow{2}{*}{41} & \multirow{2}{*}{45.5} & insulin & 0.07 & 4.00 & 1.00 & 1.74 & 1.84 \\
\hline & & & & & blood sugar & 241 & 194 & 107 & 58 & 96 \\
\hline \multirow{2}{*}{5} & \multirow{2}{*}{ S. K. } & \multirow{2}{*}{$\hat{\delta}$} & \multirow{2}{*}{55} & \multirow{2}{*}{50.5} & insulin & 0.01 & 6.00 & 6.60 & 5.40 & 1.04 \\
\hline & & & & & blood sugar & 222 & 144 & 83 & 91 & 91 \\
\hline \multirow{2}{*}{\multicolumn{5}{|c|}{ Average }} & insulin $(\mathrm{mu} / \mathrm{cc})$ & 0.100 & 4.26 & 4.16 & 3.10 & 1.22 \\
\hline & & & & & blood sugar $(\mathrm{mg} / \mathrm{dl})$ & 189 & 150 & 104 & 85 & 84 \\
\hline
\end{tabular}

$\mathrm{mg} / \mathrm{dl}, 120$ 分後では $3.10 \mathrm{mu} / \mathrm{cc} ， 85 \mathrm{mg} / \mathrm{dl} 180$ 分後では $1.22 \mathrm{mu} / \mathrm{cc}, 84 \mathrm{mg} / \mathrm{dl}$ となり之を図示すれば第 8 図の如くなる. Insulin 5 unit 注射せる場命の血中 Insulin 量は30分後に於て正常人と略々同量の 1.88 $\mathrm{mu} / \mathrm{cc}$ と最高になるが，60分，120分，180分後に於ては正常者に於ける場合よりも血中停滞遅延を認める. 
Table 15 Changes of insulin concentrations in circulating blood and blood sugar levels in each time after i.m. injection of Novo Regular Insulin $1 /$ unit/kg to normal rabbits.

\begin{tabular}{|c|c|c|c|c|c|c|c|c|}
\hline \multirow[b]{2}{*}{ No } & \multirow{2}{*}{$\begin{array}{l}\text { body } \\
\text { weight } \\
\text { (kg) }\end{array}$} & & \multirow{2}{*}{$\begin{array}{l}\text { before } \\
\text { injection }\end{array}$} & \multicolumn{4}{|c|}{ after injection } & \multirow{2}{*}{$\frac{(\min )}{240}$} \\
\hline & & & & 30 & 60 & 120 & 180 & \\
\hline \multirow[t]{2}{*}{1} & \multirow{2}{*}{2.9} & insulin & 0.32 & / & $5: 11$ & 2.48 & 0.71 & 0.28 \\
\hline & & blood sugar & 102 & 77 & 55 & 68 & 85 & 91 \\
\hline \multirow{2}{*}{2} & \multirow{2}{*}{2.5} & insulin & 0.48 & 6.01 & 4.00 & 1.04 & 0.21 & 0.24 \\
\hline & & blood sugar & 106 & 92 & 59 & 66 & 99 & 109 \\
\hline \multirow{2}{*}{3} & \multirow{2}{*}{2.7} & insulin & 0.248 & ～ & 6.97 & 3.20 & 0.45 & 0.17 \\
\hline & & blood sugar & 98 & 46 & 51 & 53 & 58 & 65 \\
\hline \multirow[t]{2}{*}{4} & \multirow{2}{*}{2.8} & insulin & 0.36 & 10.70 & ～ & 0.58 & 0.164 & / \\
\hline & & blood sugar & 96 & 76 & 54 & 69 & 86 & ～ \\
\hline \multirow[t]{2}{*}{5} & \multirow[t]{2}{*}{3.0} & insulin & 0.23 & 7.80 & 4.80 & 1.36 & 0.56 & $\zeta$ \\
\hline & & blood sugar & 105 & 52 & 63 & 72 & 115 & / \\
\hline \multirow{2}{*}{\multicolumn{2}{|c|}{ Average }} & insulin $(\mathrm{mu} / \mathrm{cc})$ & 0.324 & 8.17 & 5.22 & 1.73 & 0.42 & 0.23 \\
\hline & & $(\mathrm{mg} / \mathrm{dl})$ & 101 & 69 & 56 & 66 & 89 & 88 \\
\hline
\end{tabular}

この血中停滞は Insulin 活性のままである点を強調したい. 又血糖の降下は血中 Insulin 量の山より遙か に荤れる. 即ち $2 \sim 3$ 時間後に最低となる. 5 unit の Insulin に対して30分後の血糖降下量は正常者の 24 $\mathrm{mg} / \mathrm{dl}$ なるに刘して, 僅かに $6 \mathrm{mg} / \mathrm{dl}$ であり, 2 㭙間後に於て正常者は略々元に復するに反し, 最高

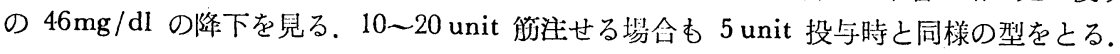

\section{2) 正常家鬼之 Alloxan 家兔}

正常家鬼に Novo Regular Insulin 1 unit $/ \mathrm{kg}$ 筋 注した埸合の血中 Insulin 量及び血糖の時間的変怔 は第15表の通りである．即ち 5 例の平均值は注射前 $0.324 \mathrm{mu} / \mathrm{cc}, 101 \mathrm{mg} / \mathrm{dl}$ であり, 注射後 30 分では $8.17 \mathrm{mu} / \mathrm{cc}, 69 \mathrm{mg} / \mathrm{dl} 60$ 分後 $5.22 \mathrm{mu} / \mathrm{cc}, 56 \mathrm{mg}$ /dl 120分後 $1.73 \mathrm{mu} / \mathrm{cc}, 66 \mathrm{mg} / \mathrm{dl} 180$ 分後 0.42 $\mathrm{mu} / \mathrm{cc}, 89 \mathrm{mg} / \mathrm{dl}, 240$ 分後 $0.23 \mathrm{mu} / \mathrm{cc}, 88 \mathrm{mg} / \mathrm{dl}$ となり，血中 Insulin 量は 30 分後最高となりその 後濑次娍少して $3 \sim 4$ 哳間後に略々元に復する. 血 糖値は60分後に於て最低となり，32 $\mathrm{mg} / \mathrm{dl}$ の低下

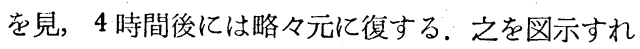
ば第 9 図の如くなる．之は正常人の場合と類似する。 一方アロキサン家鬼に Insulin を注射した場合の成 績は第16，17表の通りである. Novo Regular Insulin 1 unit $/ \mathrm{kg}$ 能注時に於ける血中 Insulin 量及び 血糖值の時間的変動は第16表の如くで 4 例の平均值 は注射前 $0.025 \mathrm{mu} / \mathrm{cc}, 318 \mathrm{mg} / \mathrm{dl}$ で注射後30分で
Fig. 9 Changes of insulin concentrations in circulating blood and blood sugar levels in each time after i.m. injection of Novo Regula Insulin/lunit/kg to normal rabbits.

Valuesare the average of five cases.

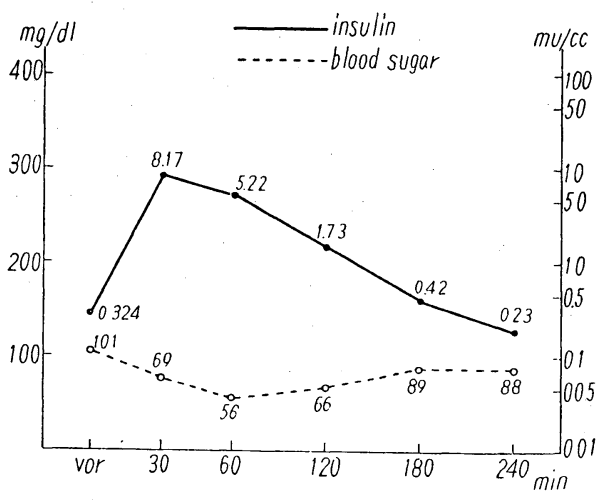


Table 16 Changes of insulin concentrations in circulating blood and blood sugar levels in each time after i.m. injection of Novo Regula Insulin $1 /$ unit/kg to alloxan rabbits.

\begin{tabular}{|c|c|c|c|c|c|c|c|c|}
\hline & \multirow{2}{*}{$\begin{array}{l}\text { body } \\
\text { weight } \\
(\mathrm{kg})\end{array}$} & & \multirow{2}{*}{$\begin{array}{l}\text { before } \\
\text { injection }\end{array}$} & \multicolumn{4}{|c|}{ after injection } & \multirow[t]{2}{*}{$(\min )$} \\
\hline No & & & & 30 & 60 & 120 & 180 & \\
\hline \multirow{2}{*}{1} & \multirow{2}{*}{2.8} & insulin & 0.084 & $\zeta$ & 4.70 & 3.68 & I & 1.60 \\
\hline & & blood sugar & 308 & 290 & 282 & 275 & 261 & 253 \\
\hline \multirow{2}{*}{2} & \multirow{2}{*}{3.5} & insulin & 0 & 6.41 & 5.00 & 3.47 & 1.16 & I \\
\hline & & blood sugar & 352 & 340 & 335 & 330 & 321 & 310 \\
\hline \multirow{2}{*}{3} & \multirow{2}{*}{3.3} & insulin & 0 & 9.20 & $\zeta$ & 3.62 & 2.15 & 1.12 \\
\hline & & blood sugar & 314 & 312 & 310 & 288 & 225 & 223 \\
\hline \multirow{2}{*}{4} & \multirow{2}{*}{2.9} & insulin & 0.02 & 9.29 & 8.30 & $\nearrow$ & 2.12 & 1.93 \\
\hline & & blood sugar & 296 & 288 & 243 & 221 & 209 & 200 \\
\hline \multirow{2}{*}{\multicolumn{2}{|c|}{ Average }} & \multirow{2}{*}{$\begin{array}{l}\text { insulin }(\mathrm{mu} / \mathrm{cc}) \\
\text { blood sugar } \\
(\mathrm{mg} / \mathrm{dl})\end{array}$} & 0.025 & 8.30 & 6.00 & 3.59 & 1.81 & 1.55 \\
\hline & & & 318 & 308 & 293 & 279 & 254 & 249 \\
\hline
\end{tabular}

Table 17 Changes of insulin concentrations in circulating blood and blood sugar levels in each time after i.m. injection of Novo Regular Insulin 2.5 units/kg to alloxan rabbits.

\begin{tabular}{|c|c|c|c|c|c|c|c|c|}
\hline \multirow[b]{2}{*}{ No } & \multirow{2}{*}{$\begin{array}{l}\text { body } \\
\text { weight } \\
\text { (kg) }\end{array}$} & & \multirow{2}{*}{$\begin{array}{l}\text { before } \\
\text { injection }\end{array}$} & \multicolumn{4}{|c|}{ after injection } & \multirow{2}{*}{$\frac{(\mathrm{min})}{240}$} \\
\hline & & & & 30 & 60 & 120 & 180 & \\
\hline \multirow{2}{*}{1} & \multirow{2}{*}{2.5} & insulin & 0.02 & I & 6.40 & 3.02 & 2.40 & 2.35 \\
\hline & & blood sugar & 380 & 288 & 198 & 132 & 98 & 86 \\
\hline \multirow{2}{*}{2} & \multirow{2}{*}{2.3} & insulin & 0 & 14.0 & 11.12 & / & 2.80 & 3.21 \\
\hline & & blood sugar & 452 & 321 & 142 & 101 & 61 & 61 \\
\hline \multirow{2}{*}{3} & \multirow{2}{*}{3.2} & insulin & 0 & 15.20 & 12.80 & 7.88 & 1.24 & I \\
\hline & & blood sugar & 416 & 352 & 310 & 179 & 102 & , \\
\hline \multirow{2}{*}{4} & \multirow{2}{*}{2.9} & insulin & 0 & 13.6 & ノ & 3.70 & 2.70 & 2.00 \\
\hline & & blood sugar & 303 & 221 & 150 & 104 & 90 & 81 \\
\hline \multirow{2}{*}{5} & \multirow{2}{*}{3.2} & insulin & $<0.01$ & 20.88 & 18.0 & 5.00 & 5.61 & 41.0 \\
\hline & & blood sugar & 351 & 350 & 310 & 234 & 15 & 414 \\
\hline \multirow{2}{*}{\multicolumn{2}{|c|}{ Average }} & insulin $(\mathrm{mu} / \mathrm{cc})$ & $<0.01$ & 15.92 & 12.08 & 4.90 & 2.95 & 1.72 \\
\hline & & $\begin{array}{r}\text { blood sugar } \\
(\mathrm{mg} / \mathrm{dl})\end{array}$ & 380 & 310 & 222 & 150 & 101 & 92 \\
\hline
\end{tabular}

は $8.30 \mathrm{mu} / \mathrm{cc}, 308 \mathrm{mg} / \mathrm{dl} 60$ 分後では $6.00 \mathrm{mu} / \mathrm{cc}, 293 \mathrm{mg} / \mathrm{dl} 120$ 分後では $3.59 \mathrm{mu} / \mathrm{cc}, 279 \mathrm{mg} / \mathrm{dl} 180$ 分後では $1.81 \mathrm{mu} / \mathrm{cc}, 254 \mathrm{mg} / \mathrm{dl} 240$ 分後では $1.55 \mathrm{mu} / \mathrm{cc}, 249 \mathrm{mg} / \mathrm{dl}$ となり之を図示したのが第10図で ある. 即ち正常家鬼に比して Insulin の血中停滞は遅延する．之は糖尿病患者に於ける場合と類似する．又 $2.5 \mathrm{unit} / \mathrm{kg}$ 筋注時の成績は第17表の如くで 5 例の血中 Insulin 量及び血糖值の平均值は, 注射前 $0.01 \mathrm{mu} /$ 
Fig. 10 Changs of insulin concentrations in circulating blood and blood sugar levels in each time after i.m. injection of Novo Regula Insulid 1 unit/kg to alloxan rabbits. Values are the average of four cases.

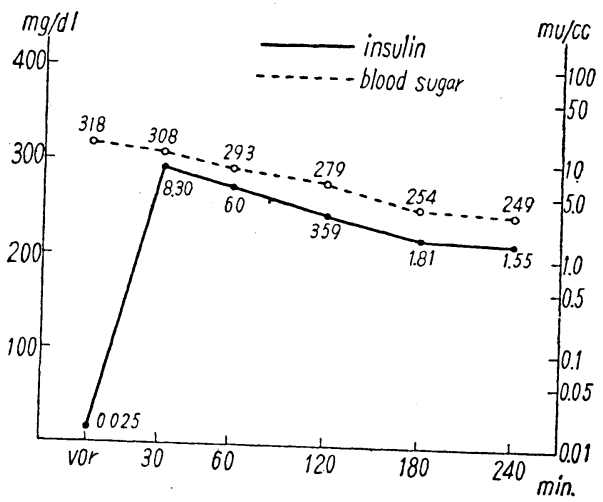

Fig. 11 Changes of insulin concentrations in circulating blood and blood sugar levels in each time after i.m. injection of Novo Regula Insulin 2.5 units $/ \mathrm{kg}$ to alloxan rabbits. Values are the average of five cases.

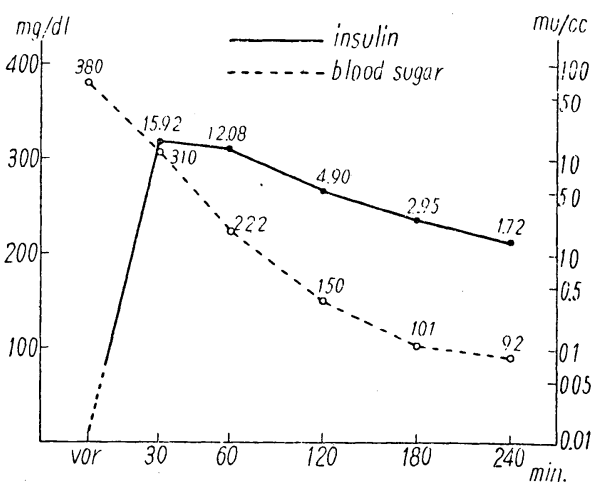

cc以下, $380 \mathrm{mg} / \mathrm{dl}$ で注射後 30 分では $15.92 \mathrm{mu} / \mathrm{cc}, 310 \mathrm{mg} / \mathrm{dl} 60$ 分後では $12.08 \mathrm{mu} / \mathrm{cc}, 222 \mathrm{mg} / \mathrm{dl}, 120$ 分 後では $4.90 \mathrm{mu} / \mathrm{cc}, 150 \mathrm{mg} / \mathrm{dl} 180$ 分後では $2.95 \mathrm{mu} / \mathrm{cc}, 101 \mathrm{mg} / \mathrm{dl} 240$ 分後では $1.71 \mathrm{mu} / \mathrm{cc}, 92 \mathrm{mg} / \mathrm{dl}$ であり之を図示すれば第11図の则くなる，即ち投与 Insulin 量の多少に拊わらず同じ様な型を示す。血糖 は正常家躳が注射後60分後に於て最低となり $45 \mathrm{mg} / \mathrm{dl}$ の降下を示すに反し，Alloxan 家鬼では 4 奘䦌後に 於て最も低く，69mg/dl の降下を見た (1 unit $/ \mathrm{kg}$ 筋注時).

\section{3) 正常犬及ひ除萃犬}

正常犬及び之に膵剔を行つた糖尿犬に, Novo Regular Insulin 0.3 unit $/ \mathrm{kg}$ 矣注時に於ける血中 Insuiln

Table 18 Changes of insulin concentrations in circulating blood and blood sugar levels in each time after i.m. injection of Novo Regula Insulin 0.3 unit $/ \mathrm{kg}$ to normal dogs.

\begin{tabular}{|c|c|c|c|c|c|c|c|}
\hline \multirow[b]{2}{*}{ No } & \multirow{2}{*}{$\begin{array}{l}\text { body } \\
\text { weight } \\
\text { (kg) }\end{array}$} & & \multirow{2}{*}{$\begin{array}{l}\text { before } \\
\text { injection }\end{array}$} & \multicolumn{3}{|c|}{ after injection } & \multirow{2}{*}{$\begin{array}{l}(\min ) \\
180\end{array}$} \\
\hline & & & & 30 & 60 & 120 & \\
\hline 1 & 10 & $\begin{array}{l}\text { insulin } \\
\text { blood sugar }\end{array}$ & $\begin{array}{l}0.08 \\
91\end{array}$ & $\begin{array}{l}3.12 \\
62\end{array}$ & $\begin{array}{l}1.44 \\
65\end{array}$ & $\begin{array}{l}0.05 \\
78\end{array}$ & $\begin{array}{l}0.08 \\
86\end{array}$ \\
\hline 2 & 16 & $\begin{array}{l}\text { insulin } \\
\text { blood sugar }\end{array}$ & $\begin{array}{l}0.19 \\
75\end{array}$ & $\begin{array}{l}3.44 \\
56\end{array}$ & $\begin{array}{l}0.27 \\
52\end{array}$ & $\begin{array}{l}0.28 \\
59\end{array}$ & $\begin{array}{l}0.23 \\
78\end{array}$ \\
\hline 3 & 7.2 & $\begin{array}{l}\text { insulin } \\
\text { blood sugar }\end{array}$ & $\begin{array}{l}0.24 \\
86\end{array}$ & $\begin{array}{l}4.00 \\
51\end{array}$ & 59 & $\begin{array}{l}0.23 \\
68\end{array}$ & $\begin{array}{l}0.12 \\
79\end{array}$ \\
\hline 4 & 7.5 & $\begin{array}{l}\text { insulin } \\
\text { blood sugar }\end{array}$ & $\begin{array}{l}0.20 \\
81 \\
\end{array}$ & $\begin{array}{l}4.20 \\
49 \\
\end{array}$ & $\begin{array}{l}2.00 \\
58\end{array}$ & $\begin{array}{l}0.58 \\
79\end{array}$ & $\begin{array}{l}0.10 \\
83\end{array}$ \\
\hline \multicolumn{2}{|c|}{ Average } & $\begin{array}{l}\text { insulin }(\mathrm{mu} / \mathrm{cc}) \\
\text { blood sugar }(\mathrm{mg} / \mathrm{dl})\end{array}$ & $\begin{array}{l}0.18 \\
83\end{array}$ & $\begin{array}{l}3.69 \\
55\end{array}$ & $\begin{array}{l}1.23 \\
59\end{array}$ & $\begin{array}{l}0.29 \\
71\end{array}$ & $\begin{array}{l}0.13 \\
82\end{array}$ \\
\hline
\end{tabular}


Table 19 Changes of iusulin concentrations in circulating blood and blood sugar levels in each time after i.m. injection of Novo Regula Insulin 0.3 unit $/ \mathrm{kg}$ to depancreatized dogs.

\begin{tabular}{|c|c|c|c|c|c|c|c|c|}
\hline \multirow[b]{2}{*}{ No } & \multirow{2}{*}{$\begin{array}{l}\text { body } \\
\text { weight } \\
(\mathrm{kg})\end{array}$} & & \multirow{2}{*}{$\begin{array}{l}\text { before } \\
\text { injection }\end{array}$} & \multicolumn{4}{|c|}{ after injection } & \multirow{2}{*}{$\frac{(\min )}{240}$} \\
\hline & & & & 30 & 60 & 120 & 180 & \\
\hline \multirow[t]{2}{*}{1} & \multirow[t]{2}{*}{10} & insulin & 0 & 2.72 & 2.54 & 2.50 & 0.80 & \\
\hline & & blood sugar & 292 & 201 & 138 & 76 & 81 & 139 \\
\hline \multirow{2}{*}{2} & \multirow{2}{*}{16} & insulin & $<0.01$ & 2.80 & 1.84 & 0.76 & 1.52 & $\gamma$ \\
\hline & & blood sugar & 330 & 251 & 210 & 181 & 198 & \\
\hline \multirow{2}{*}{3} & \multirow{2}{*}{7} & insulin & $<0.01$ & 5.60 & 2.24 & 1.52 & 2.32 & 7 \\
\hline & & blood sugar & 198 & 111 & 99 & 81 & 103 & $\gamma$ \\
\hline \multirow{2}{*}{4} & \multirow{2}{*}{7.5} & insulin & 0 & 5.20 & 4.00 & 0.36 & 0.44 & 0.16 \\
\hline & & blood sugar & 320 & 306 & 285 & 209 & 279 & 331 \\
\hline \multirow{2}{*}{\multicolumn{2}{|c|}{ Average }} & insulin $(\mathrm{mu} / \mathrm{cc})$ & $<0.01$ & 4.08 & 2.66 & 1.29 & 1.27 & ノ \\
\hline & & $\begin{array}{r}\text { blood sugar } \\
(\mathrm{mg} / \mathrm{dl})\end{array}$ & 285 & 217 & 183 & 137 & 165 & 1 \\
\hline
\end{tabular}

Fig. 12 Changes of insulin concentrations circulating blood and blood sugar levels in each time after i.m. injection of Novo Regular Insulin 0.3 unit/kg to normal dogs.

Values are the average of four cases.

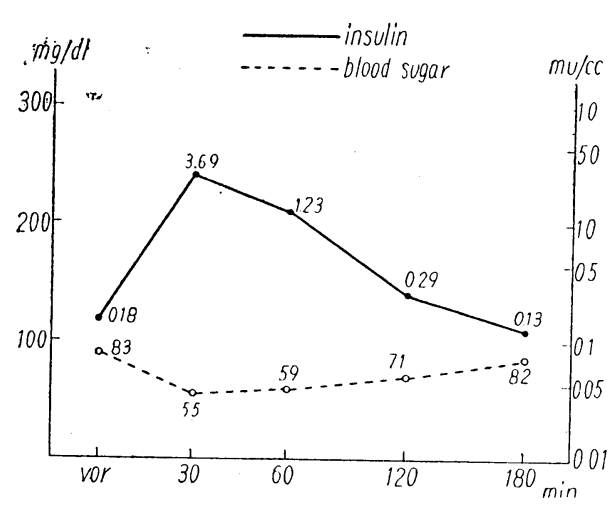

Fig. 13 Changes of insulin concentrations in circulating blood and blood sugar levels in each time after i.m. injection of Novo Regula Insulin 0.3 unit $/ \mathrm{kg}$ to depancreatized dogs. Values are the average of four cases.

量及び血糖值の時間的変動は第 $18 ， 19$ 表の如くで，4例の平均佔は，正常犬に於ては注射前 $0.18 \mathrm{mu} / \mathrm{cc}$, $83 \mathrm{mg} / \mathrm{dl}$ であり，注射後30分では $3.69 \mathrm{mu} / \mathrm{cc} ， 55 \mathrm{mg} / \mathrm{dl}$ となり，更に60分後には $1.23 \mathrm{mu} / \mathrm{cc}, 59 \mathrm{mg} / \mathrm{dl}$ 120分後には $0.29 \mathrm{mu} / \mathrm{cc}, 71 \mathrm{~cm} / \mathrm{dl} 180$ 分後には $0.13 \mathrm{mu} / \mathrm{cc}, 82 \mathrm{mgdl}$ となり，之を図示すれば第12図の 如くなる。一方除脪犬に於ては，注射前 $0.01 \mathrm{mu} / \mathrm{cc}$ 以下， $285 \mathrm{mg} / \mathrm{dl}$ であり，注射後30分では $4.08 \mathrm{mu} /$ $\mathrm{cc}, 217 \mathrm{mg} / \mathrm{dl} 60$ 分後には $2.66 \mathrm{mu} / \mathrm{cc}, 183 \mathrm{mg} / \mathrm{dl} 120$ 分後には $1.29 \mathrm{mu} / \mathrm{cc}, 137 \mathrm{mg} / \mathrm{dl} 180$ 分後には 1.27 $\mathrm{mu} / \mathrm{cc}, 165 \mathrm{mg} / \mathrm{dl}$ となり之を図示すれば第13図の如くなる。即ち正常大の場合は，正常人或は正常冢象之 同様30分後に於て血中 Insulin 量は最高となり，その後泍次減少して 3 㭙間後には全く元に復する。血糖 
はそれに従い娍增する。除腊犬に於ては正常犬に比して，Insulin の血中停滞は遅延する，之は糖尿病患者 或は Alloxan 家雨に於ける埸合と類似する。即ち糖尿病体に於て, Insulin が速やかに破壊又は不活性化 せられるのではなかろうかと云う予想は見事に裏切られて，かえつて之等に於ては Insulin の血中停滞が遅 延する事が明らかになつた。

\section{第3節 小括並びに考按}

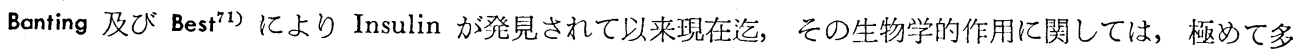
くの研究が発表され, 広く糖, 脂質, 蛋白質等の代謝迄その影響を受けている事が明らかになり, Insulin それ自体の代謝に関しても，最近に到る迄殆んど不明であつたが，近年放射性物質の利用が后く応用され， 次第に解明されつつある. 更に Insulin の作用機序に関しても種々論議されているが，未だに従来の多くの

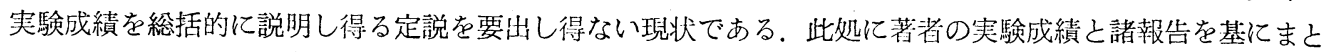
めをかねて小考を加える。

Stadie et $\mathrm{al}^{732}$. Elgee et $\mathrm{al}^{73)}$. Welsh et $\mathrm{al}^{7475)}$. Solmon et $\mathrm{al}^{76}$. 等は放射性物質で label した Insulin t 利用して, Insulin の生体内に於ける代謝或いは作用機序に大きな進歩をもたらした。

人間に於ける Insulin I ${ }^{131}$ を与えての血中濃度の变化については, Welsh et $\mathrm{al}^{\left.747^{75}\right)}$. Williams ${ }^{77)}$, Solmon et $\mathrm{al}^{76)}$ 等の成績に依れば, 非糖尿病体に Insulin $I^{131}$ を静注すると速やかに血中から消失するばかりで伹 く, 速やかに組織に於て分解され，放射能は分解終末産物 $\mathrm{I}^{131}$ となつて尿中に排泄される事に一致を見る。 一方糖尿病思者に於ける場合は, Welsh et $\mathrm{al}^{74775}$. Williams ${ }^{77}$ )等の成績に依れば, Insulin 治療を受けた事の ない 6 例では，非糖尿病対照例之差堂を認妨なつた。 又6 週間以上 Insulin 治療を受けた糖尿病息者 57 例 を，24時間 Insulin 投与を中止しての成續では，12例は対照例と大差を浔めなかつたが，45例は Insulinの 分解が遅れて血中停滞を示すと云う. 即ち Insulin の血中停滞遅延は, Insulin の分解遅延であり, 之の原 因は長期 Insulin 治療の有無に存し，糖尿病の存否と関係なしとしているが，著者の笑験成績では，之之異 り，糖疗病患者に注射せられた一定量の Insulin が, Insulin 治療の有無に関係なく，健康者におけるより

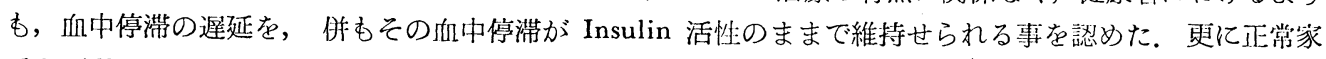

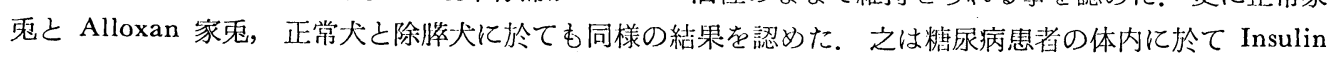
がより早く分解される事により，糖尿病が惹起せられるものでないと云う事を明らかにする。乙の糖尿病休 亿於ける血中停滞遅延に関しては, Stadie et al ${ }^{72)}$. Hougaard et al ${ }^{79)}$ 等の説を基に, Insulin が作用を発挥す るには, その作用の場に Insulin と結合して Insulin 活性を作り出す受容者が必要であり, 高血糖悲起原 因が Insulin の絶対的欠乏でなく，相対的欠乏 ${ }^{16)}$ にある事より，此の受容考即ち末杪の Insulin を利用す べき機能が低下していると考えれば理解出来る。

故に糖症病は血中に於ける活性 Insulin の低下にその原因を発するものでなく，血中に於けるInsulin を 利用すべき末㡊に於ける变化，例えば補体結合反応代於ける障碍の如く，Insulin を取入れるべき能力を娍 弱せしめる点に求められなければならない，若し末梢に於けるInsulin を取入れる能力が1/10に減少したと 仮定するならば，10倍量の或はそれ以上の Insulinがやつと糖消費を等量に補い得べく，此処にも Insulin 産生促進の強要による $\beta$ 細胞の疲労, 従つて Gegen Regulations Diabetes 亿於ける Insulin 量低下の原 因を想像する事が出来る。事実 $\beta$ 細胞の機能を元進せしめるが如き条件 (Insulin 分沁促進) 下に於ては,

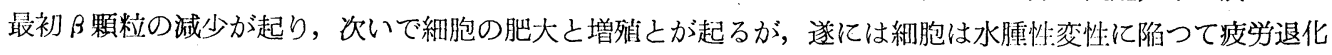
する事が明らかにせられ (Woerner ${ }^{80)}$.Dunn ${ }^{81)}$ )，乙れに随伴して生体の Insulin 量が低下して来るのは当然 であり，更には Insulin が少ないと云う事も末梢組織に於ける Insulin 利用能の低下を夢起すると云う恵循 環を想像せしめる。

\section{第四章 Insulin の作用機序に対する 2.3 の検討}

\section{第 1 節 Alloxan ラット横隔膜の Insulin 効果}

Oriental 固型飼料を以て飼育せる, 休重 $120 \mathrm{~g}$ 前後の Wister 采ラットの腹腔内に, Alloxan $20 \mathrm{mg} / 100 \mathrm{~g}$ 
Table 20 Insulin effect of alloxan rat diaphragm.

\begin{tabular}{c|c|c|c|c}
\hline & \multicolumn{2}{|c|}{$\begin{array}{c}\text { glucose uptake } \\
\mathrm{mg} / \mathrm{dl} / \mathrm{gr} \text { dry weight }\end{array}$} & \multicolumn{2}{|c}{$\begin{array}{c}\text { Insulin effect } \\
\mathrm{mg} / \mathrm{dl} / \mathrm{gr} \text { dry weight }\end{array}$} \\
\cline { 1 - 2 } $\begin{array}{c}\text { Insulin conc. } \\
\mathrm{mu} / \mathrm{cc}\end{array}$ & $\begin{array}{l}\text { normal } \\
\text { diaphragm }\end{array}$ & $\begin{array}{l}\text { alloxantized } \\
\text { diaphphragm }\end{array}$ & $\begin{array}{l}\text { normal } \\
\text { diaphragm }\end{array}$ & $\begin{array}{l}\text { alloxantized } \\
\text { diaphragm }\end{array}$ \\
\hline 0 & 21.21 & 17.89 & & \\
0.1 & 24.40 & 20.38 & 3.19 & 2.49 \\
1.0 & 25.46 & 21.51 & 4.25 & 3.62 \\
10 & 29.61 & 24.20 & 8.40 & 6.31 \\
100 & 40.48 & 35.21 & 19.27 & 17.32 \\
1000 & 60.75 & 50.13 & 39.54 & 32.24 \\
\hline
\end{tabular}

(blood sugar average $208 \mathrm{mg} / \mathrm{dl}$ )

Table 21 Insulin effect of rat diaphragm of administed with glucagon

\begin{tabular}{l|c}
\hline \multicolumn{1}{c|}{ normal rat diaphragm } & $40.17 \mathrm{mg} / \mathrm{dl} / \mathrm{gr}$. dry weight \\
\hline $\begin{array}{l}\text { rat diaphragm of administed with } \\
\text { glucagon }\end{array}$ & $39.28 \mathrm{mg} / \mathrm{dl} / \mathrm{gr}$. dry weight \\
\hline
\end{tabular}

(Medium : 200mg/dl sugar phosphate buffer solution with Insulin 100mu/cc)

Table 22 Influences of the added glucagon upon Insulin effect of normal rat diaphragm

\begin{tabular}{c|c|c|c|c}
\hline \hline medium & $\begin{array}{c}200 \mathrm{mg} / \mathrm{dl} \text { sugar buffer } \\
\text { slucagon conc. }\end{array}$ & difference & $\begin{array}{l}\text { 200mg/dl sugar buffer } \\
\text { solution with Insulin } \\
\text { 100mu/cc }\end{array}$ & difference \\
\hline 0 & $21.40 \mathrm{mg} / \mathrm{dl} / \mathrm{gr}$. & & $39.04 \mathrm{mg} / \mathrm{dl} / \mathrm{gr}$. & $34.21 \mathrm{mg} / \mathrm{dl} / \mathrm{gr}$. \\
$5 \gamma / \mathrm{cc}$ & $20.30 \mathrm{mg} / \mathrm{dl} / \mathrm{gr}$. & -1.10 & -4.83 \\
$50 \gamma / \mathrm{cc}$ & $15.29 \mathrm{mg} / \mathrm{dl} / \mathrm{gr}$. & -6.11 & & \\
\hline
\end{tabular}

を注射して糖尿病を発生せしめ，約 1 週間高血糖を持続せるものを選び实験に供した. 使用 Alloxan ラッ ト12匹の血糖值は 138〜245mg/dl 平均 $208 \mathrm{mg} / \mathrm{dl}$ であつた，実験方法は第 1 章で述べた横隔膜法と同様 に行い，正常ラット横隔膜の糖摂取能，Insulin 效果と比較検討した，実騟成績は第20表の如くで，各濃度 の添加 Insulin そ対する Alloxan ラット横隔膜の Insulin effect は正常ラット横隔膜のそれより明らかに 低下しており，Alloxan 糖尿ラットの末梢組織に於ける糖掑取能及び Insulin 利用能は，可成り減弱して いるものと思われる.

第2節 Insulin effect に及ぼす Glucagon の影響

1) Glucagon $100 \gamma$ を筋注せるラットを，30分後断頭屠殺した横隔膜の，Insulin $100 \mathrm{mu} / \mathrm{cc}$ 含有 Medium 中に於ける Glucose uptake は第21表の如くで, Insulin 利用能は正常のものと殆んど変らない. 淌 Glucagon 筋注30分後に於けるラットの血糖值は 108〜110 mg/dl と正常より高值を示した. Glucagon は Glucagon-Lilly を使用した.

2) Glucagon を in vitro で作用させた場合の実験成績は第22表の如くで，Insulin を含有しない Medium 中に於て, Glucagon を添加しない場合の Glucose uptake は $21.40 \mathrm{mg} / \mathrm{dl}$ であり, Glucagon $5 \gamma /$ cc 添加せる場合は $20.30 \mathrm{mg} / \mathrm{dl}$ と 1.10 の，50 $/ \mathrm{cc}$ 添加せる場合は $15.29 \mathrm{mg} / \mathrm{dl}$ と 6.11 の糖椇取能の 
Table 23 Influences of prepared glucagon upon Insulin effect of normal rat diaphragm.

\begin{tabular}{c|c|c|c|c}
\hline & $\begin{array}{c}\text { 200mg/di sugar buffer } \\
\text { medium }\end{array}$ & difference & $\begin{array}{l}\text { 200mg/dl sugar buffer } \\
\text { solution with Insulin } \\
\text { 100mu/cc }\end{array}$ & difference \\
\hline 0 & $22.42 \mathrm{mg} / \mathrm{dl} / \mathrm{gr}$. & & $39.48 \mathrm{mg} / \mathrm{dl} / \mathrm{gr}$. & \\
$10 \gamma / \mathrm{cc}$ & $20.64 \mathrm{mg} / \mathrm{dl} / \mathrm{gr}$. & -1.78 & $34.77 \mathrm{mg} / \mathrm{dl} / \mathrm{gr}$. & -4.71 \\
$100 \mathrm{r} / \mathrm{cc}$ & $16.71 \mathrm{mg} / \mathrm{dl} / \mathrm{gr}$. & -5.71 & $31.17 \mathrm{mg} / \mathrm{dl} / \mathrm{gr}$. & -8.31 \\
\hline
\end{tabular}

低下を見る。一方 Insulin 100mu/cc 含有せる Medium 中に於て, Glucagon を添加しない場合の Glucose uptake は $39.04 \mathrm{mg} / \mathrm{dl}$ なるに対し, Glucagon $5 \mathrm{r} / \mathrm{cc}$ 添加せる場合は $34.21 \mathrm{mg} / \mathrm{dl}$ と 4.83 の, Insulin 利用能の低下を認める.

3）更に正常ラットの横隔膜を Glucagon $10 r / c c .100 \gamma / \mathrm{cc}$ 含有液中に15分間， $38^{\circ} \mathrm{C}$ 亿保存した場合 (15 分後取出し Glucagon をよく洗い落す) の成績は第23表の如くで，Insulin を含有しない Medium 中に於 ては，夫々 1.78，5.71 の，又 Insulin 100mu/cc 含有せる Medium 中に於ては，夫々，4.71，8.31 と糖 掑取能及び Insulin 利用能の減弱を認める.

\section{第 3 節 小括及び考按}

前章に於て糖尿病体の末梢に於ける血中 Insulin 利用能の低下を主張して来たが，乙の事実を証明すべく 本実験を行つた。 即ち Insulin が存在しない場合の Alloxan ラット横隔膜の Glucose uptake 及び Insulin が存在する場合の Insulin effect は明らかに低下している.Villee and Hastings' ${ }^{31)}$ は Alloxan 糖尿病 ラット横隔膜の糖原合成が対照に比して著明に減弱している事を，又 Glock $^{39)}$, Bloom ${ }^{82)}$, Milstein ${ }^{83)}$ 等は肝

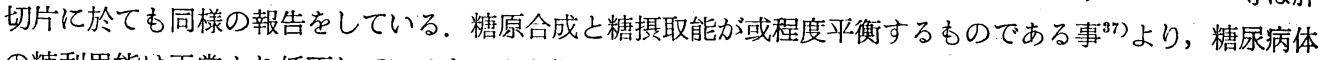
の糖利用能は正常より低下しているものと判断して差支えない. 更に Insulin を添加した場合の uptake の 減少より，Insulin 利用能の低下を証明したが，Insulin の直接作用が組織内への葡萄糖侵入の晆段にのみ (その後の糖の運命は問わず）限られている事 ${ }^{84}{ }^{85}$ )86)87) より考え合わせれば, 糖尿病体の末梢組織の利用能 の低下は，Insulin を取入れるべき末梢組織が或る原因で正常に機能していない，即ち Insulin を利用すべ き末梢の変化を想像せざるを得ない.

糖尿病動物に於ける中間代謝反応系の速度の低下も, 恐らくこの一時的作用の遅延に従属するものであろ う(例えば Glycogenolysis の変化 $)^{88)}$.

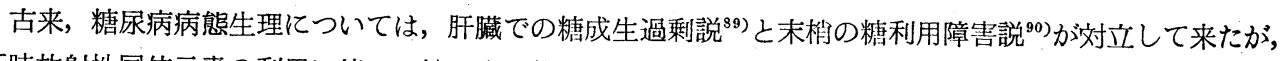
近時放射性同位元素の利用に伴い，糖尿病動物の代謝異常が解明されるに及び，糖尿病に於ては組織の糖利 用能乃至酸化障害の存在を証明する成績が相次いで現われ, 糖利用障害説が積極的に支持される様になつた が，著者も益々その感を深くしたものである.

次で Insulin が末梢組織に 取入られて 作用すると考えるならば， Insulin に似た 構造のものが Insulin inhibitor としての働きをするかも知れないと考えて, Glucagon の影響を検討した.

又別な意味に於て, Glucagon の糖代謝に及ばす作用の中で確認されているものは, 肝の Glycogenolysis の速度を促進して, 一過性ではあるが，急激に発生する高血糖蒛起作用 ${ }^{99}$ )であるから, 血糖降下を主な作用 とする Insulin との拮抗性に関しても興味ある問題である.

Bürger $^{91)}$, Erlick ${ }^{9293)}$, Rossi ${ }^{94)}$, 吉岡 ${ }^{95)}$ 等は Glucagon Insulin との協調作用を主張しているが，乙れに対 して, Ferner ${ }^{96)}$, Drury et $\mathrm{al}^{78)}$. Young ${ }^{55)}$ 等は, Glucagon は Insulin の作用に怙抗すると云つている. 更に Candela ${ }^{97}{ }^{93)}$ はラット横隔膜法により，各濃度の Insulin に対して，一定量の Glucagon (200r/cc) を添加 し, Insulin effect が Glucagon に依り抑制される事を報告している。一方阿部等 ${ }^{99}$ はラット横隔膜法に準 拠して, Glucagon $5 r / \mathrm{cc}$ の添加に依り Insulin 効果の促進を認めている. 之は Candela の報告と相反す る.との両者の荎違について問題になるのは Glucagon の濃度であるが，著者は阿部等と同様 $5 \gamma / \mathrm{cc}$ 涯加 
実験に於ても, Insulin effect の抑制を認めた. 更に予め Glucagon 液中に浸した横隔膜片に於ても, 同様 Glucose uptake 及び Insulin effect の抑制を認めた。依つて Glucagon は肝の Glycogenolysis を促進す る他，末梢に於ては Insulin の利用を抑制し， Insulin inhibitor '之恩なされる如く作用して，血糖を上昇 せしめるあのと考える.

結語

1）横隔膜法に依る Insulin 測定法について検討し，測定条件に若干の考察を加え，Insulin 作用濃度標 準曲線が, Insulin 濃度と $\Delta$ Glucose uptake の両対数に於て直線回帰が成立し，Insulin 量は Juptake よ り回帰方程式 $\log y=3 / 10 \log x+\log 40$ 亿依つて算出される事を明らかにした。

2）正常体之糖尿病体の血中 Insulin 量は次の如くであつた．正常人 $0.339 \pm 0.081 \mathrm{mu} / \mathrm{cc}$, 糖尿病患者 $0.125 \pm 0.115 \mathrm{mu} / \mathrm{cc}$ ，正常家鬼 $0.355 \pm 0.125 \mathrm{mu} / \mathrm{cc}$ ，Alloxan 家鬼 $0 \sim 0.08 \mathrm{mu} / \mathrm{cc}$ ，正常犬 $0.158 \pm 0.082$ $\mathrm{mu} / \mathrm{cc}$ 除膵犬 0 ～$<0.01 \mathrm{mu} / \mathrm{cc}$. 即ち糖尿病体に於ける Insulin activity の低下を明らかにした。

3）負荷 Insulin が正常体より糖尿病体に於て血中停滞の遅延する事を確認し，Insulin 代謝に若干の検 討を加えると共に糖尿病の原因が血中 Insulin 活性の低下に根源を発するすので無く，末梢に於けるInsulin 利用能の低下に原因するとの説に根拠を与えた。

4） Alloxan ラット横隔膜により, 糖尿病体の末梢組織の Insulin 利用能が低下している事を証明した。

5）Glucagon が末梢に於ける糖摂取能及び Insulin 利用能を抑制し， Insulin inhibitor として働く成 績を得 Insulin の作用機序並びに糖尿病発生機序に若干の考察を加えた.

稿を終るに臨み，本研究に対して終始御指導を仰ぎ，御校閲を睗わつた吉田助教授に束心より感謝致しま す.

\section{参 考 文 献}

1) Sanger, F. : Ciba Foundation Colloq. on Endocrinol. $9: 110,1956 . \quad 2)$ Gemmill, C.L. : Bull. Johns Hopk. Hosp. $66: 232,1940 . \quad$ 3) Gemmill, C.L. : Bull. Johns. Hopk. Hosp. $68: 329,1941$. 4) Stadie, W.C. and J.A. Zapp. : J. Biol. Chem. $170: 55,1947 . \quad 5)$ Krahl, M.E. and C.R. Park : J. Biol. Chem. $174: 939,1948.6$ 6) Permutter, M. et al. : Endocrinology. $30: 442,1952 . \quad 7$ ) Groen, J. et al : J. Clin. Invest. $31: 97,1952 . \quad$ 8) Randle, P.J. : Brit. Med. J. $1: 1237,1954$. 9) Randle, P.J. : J. Endocrinology. $14: 82,1956$ 10) Vallance-Owen, J, et al : Lancet, $1: 68$, 1954. 11) Vallance-Owen,J. et al : Ibid., $1: 583,1955$. 12) 竹内節弥他 : 日薬理誌, $53: 740$, 1957. 13) 竹内節弥他 : 日内泌誌, $32: 176,1956.114)$ Willebrands, A.F. et al : Ned. Tschr. Genesk, $100: 817,1956$. 15) 竹内節弥 : 日内泌誌, $34: 13,1958.116)$ Duncan, G.G. : Disease of Metabolism, 3rd Edition, P 858, 1952. 17) Soskin, S. : 糖代謝, 吉岡訳, P 276, 1956. 18) Willebrands, A.F. et al : Science, $112: 277,1950.19)$ 吉川他 : ワールブルグ検圧計, 化学の領 域増刊, $13: 101,1941$ 20）中山他：第31回日内泌会発表, 1958. 21) Hansen, R.G.: J. Biol. Chem. $192: 243,1951.22)$ Krahl, M.E. et al :J. Biol. Chem. $170: 607,1947.22$ 23) Devel, H.J. and A. Davis : J. Biol. Chem. $146: 649,1942 . \quad 24)$ Kerly, M. andJ.H. Ottaway : J. Physiol, $123: 534,1954 . \quad 25)$ Gilmore, R.C. and L.T. Samuels : J. Biol. Chem. $181: 812,1949.26$ ) Lundbaeck, K. and J.A.F. Steveson : Federation Proc. $7: 75,1948$ 2 27$)$ Kerly, M. and J.H. Ottaway : J. Physiol, $123: 516,1954.28)$ 馬場茂明他 : 日内泌誌, $35: 54,1959.29$ ) Colowick, S.P., G.T. Cori and M.W. Slein : J. Biol. Chem. $168: 583,1947 . \quad 30)$ Park, C.R. : Carbohydrate Metabolism, Johns Hopkins Press. P. 43, $1952 . \quad 31)$ Villee, C.A. and A.B. Hastings : J. Biol. Chem. 197 : 673, 1949. 32) 辻昇三他 : 日内泌誌, $34: 31,1958,33)$ 小島正守 : 日内泌誌, $33: 915$, 
1957.

34) Gemmill, C.L. et al : Bull. Johns Hopkins Hosp. 68 :50, 1941

35) Gey, G.O. and M.K. Gey : Am. J. Caneer, $27: 45,1936$.

36) Villee, C.A. et al :J. Biol. Chem. $195: 287,1952$.

37) Walaas, E. and O. Walaas: J. Biol. Chem. $195: 367,1952$.

38) Krahl, M.E. : Am. New York Acad. Sc. $54: 649,1951$.

39) Glock, G.E. : Biochem. J. $63: 520,1956$. 40) Soskin, S. and R.Levine : Carbohydrate Metabolism, 1952. 41) Hechter, O.R. et al : Proc. Soc. Exp. and Med. 46 : 390, 1941. 42) 竹内節弥他：膵藏上内分泌，阿部他著より P 242 .

43) Vallance-Owen, J. et al : Lancet. II : 983,1954 .

44) Kelly, J.D.C. : Lancet, $1: 668,1956$.

45) Vallance-Owen, J.

et al : Lancet, II : 583, 1954. 46) Park, C.R. : Phosphorus Metabolism, Johns Hopk. Press, $2: 634$, 1952. 47) Bornstein, J. and C.R. Rark: J. Biol. Chem. $205: 503,1953 . \quad 48)$ Bornstein, J. : J. Biol. Chem. $205: 513$, 1953

49) Park, C.R. and M.E. Krahl : J. Biol. Chem. $181: 247,1949$.

Ottawoy, J.H. : Nature, $167: 1064,1951$.

51) Ottaway, J.H. : Brit. Med. J. 2 : 257, 1953.

52) Randle, P.J. and F.G. Young : J. Endocrinol. $13: 335,1956$.

53) Bornstein, J. and M.E. Krahl : Nature, $173: 949,1954$.

54）吉田秀雄他：日内泌誌，34：705，1958, “

55) Young, F.G. : Recent. Prog. Hormone Res. $8: 471,1953$. 732, 1951. 57) Bornsłein, J. and R.D. Lawrence : Brit. Ned. J., II : 1541, 1951. 58) Willebrands, A.F. et al : Diabetes, $5: 378,1956$. 田弘三他：日内泌彭，34:379, 1958. 59）峰下銕雄他：日内泌誌，33:815，1957. 60) 山 62) Gellhorn, E. et al : Endocrinology, $29: 849,1941$ 61) Gellhorn, E. et al : Endocrinology, $29: 137,1941$.

64) Goldner, M.G. and G. Gomori : Endocrinology, $33: 297,1943$.

63) Dunn, J.S. et al : Lancet, $1: 484,1943$. J. Med. Sci. 208 : 450, 1944. 66) Bailey, C.B. : J. Amer. Med. Assoc. 122 : 1165, 1943. Goldner, M.G. and G. Gomori, : Endocrinology, $35: 24,1944$. 1953. 69) 小坂樹徳他：日内必誌，33:571，1957.

68) 小坂樹徳他：最新医学, $8: 714$, Amer. Diabetes, Ass. $7: 169,1947$.

71) Banting, F.A. and C.H. Best : J. Labor. Clin. Med. $7: 251$, 1922. 72) Stadie, W.C. et al : J. Biol. Chem. $199: 729,1952$. 73) Elgee, N.J. et al : J. Glin. Invest. $33: 1252,1954$. 74) Welsh, G.W. et al : Amer. J. Med. $21: 324,1956$. Welsh, G.W. et al : Diabetes, $5: 15,1956$. 77) Williams, R.H. : Metabolism, $5: 128,1956$.

76) Solmon, A.B. et al : J. Clin. Invest. $35: 170,1956$. 79) Haugaard, N. et al : J. Biol. Ghem. $211: 289,1954$. 78) Drury, D.R. et al : Diabetes, $3: 129,1954$.

81) Dunn, J.S. et al : J. Path. Bact., $55: 245,1943$. 80)Woerner, C.A. : Anat. Rec. $71: 31,1939$. 83) Milstein, S.W. : Proc. Soc. Exp. Biol. Med. 92 : 632, 1956. 82) Bloom, B. : J. Biol. Chem. $215:$ 467, 1955. Physiol., $120: 761,1937$. 85) Soskin, S. and R. Levine : Am. J. Physiol. 129 : 782, 1940. Best, C.H. et al : Proc. Roy. Soc. London, B. $100: 55,1926$ 87) Best, C.H. et al : Proc. Roy. Soc. London, B. 100 : 32, 1926 88) Soskin, S. : 糖代謝, 吉岡訳. P 202, 1956.

89) Noorden, C. : Die Zuckerkrankheit. Berlin. Springer 1928.

90) Naunyn, B. : Der Diabetes Mellitus. Wien. Hölder, 1899. 91) Bürger, H. and W. Brandt : Z. Ges. Exp. Med. $96: 375,1935$. 92) Erlick, H. et al : J. Clin. Invest. $34: 1830,1955$. 93) Erlick, et al : J. Clin. Invest., $35: 757,1956$.

94) Rossi, E. et al : Schweiz. Med. Wschr. 87 : 1009, 1957. 95) 吉岡一：日内泌誌，3:97，1956.

96) Ferner, H. : Das Inselsystem des Pankreas, Georg Thieme, 1952. 97) Candela, J.L.R. : Ciba Foundation Colloq. on Endocrinol. $6: 233,1953$. 98) Candela, J.L.R. and R.R Candela: Ciba Foundation Colloq. on Endocrinol. $9:$ 194, 1956.

99）阿部正和他：内分必，3:299，1956. 